\title{
Reference in Discourse and Models of Article Grammaticalization
}

\subsection{Introductory Remarks}

The rise of articles, both definite and indefinite, is an example of a process of grammaticalization, i.e., a type of language change whereby lexical items gain grammatical meanings or grammatical items gain more grammatical meanings while being subject to certain changes, such as erosion of phonetic and semantic substance, acquisition of a more fixed position in the phrase or loss of independence, as in cliticization or affixation (see Kuryłowicz 1965, Lehmann 1995, Heine 2002, Hopper and Traugott 2003, Lehmann 2004). The process of grammaticalization of the articles has been studied within grammaticalization studies, among others Greenberg (1978), Givón (1981), Heine (1997), Dahl (2004), De Mulder and Carlier (2011), Skrzypek (2012, 2013), to name but a few. Another approach to grammaticalization of the articles has been couched in generative terms, and its foremost proponents with respect to North Germanic include van Gelderen (2007), Faarlund (2007, 2009) and Stroh-Wollin (2009, 2015, 2016).

In the following, we adopt the grammaticalization studies approach, discussing the model of the rise of the definite article first and the model of the rise of the indefinite second, concluding with an attempt at joining them. The grammaticalization processes which result in the formation of articles are not universal, yet they exhibit cross-linguistic regularities, with respect to both the etymologies of the articles and their later developments. Our study focuses on a group of closely related languages; nevertheless, we aim to develop a model that may have a more universal application in diachronic studies of (in)definiteness. In this chapter, the theoretical and terminological discussions are limited to the terms, concepts and hypotheses crucial for the study of grammaticalization of articles only, omitting a wider discussion of reference in general. 
The first study of the development of the definite article, on which later studies of its grammaticalization are based, is Greenberg (1978). In that paper on the rise of gender markers, Greenberg proposes a development from a demonstrative through a definite article, which in later stages of grammaticalization turns into a nominal marker signaling the gender of the noun. Greenberg does not analyze the transition from a demonstrative to an article in any more detail. In later studies, notably De Mulder and Carlier (2011), the grammaticalization chain from a demonstrative to a definite article is described as consisting of at least three crucial stages: 1 ) the incipient article used as a direct anaphoric marker, 2) the incipient article used as an indirect anaphoric marker, and 3) the incipient article used as a unique marker.

Virtually all studies of definiteness, either synchronic or diachronic, stress the fact that the definite article has a wide range of uses, which are difficult to subsume under one semantic category or notion. Thus, anaphora is regarded as an instance of familiarity, when the hearer is 'reminded' by means of the definite article that the discourse referent has already been introduced into the discourse. On the other hand, the use of the definite article with referents such as sun is regarded as being due to their uniqueness, which renders previous mentions unnecessary for their successful resolution. Numerous attempts have been made to define all uses as building on either the familiarity or the uniqueness of the discourse referent, always with a proviso that the category in question is weakened; in fact, Roberts (2003), a proponent of the familiarity hypothesis, does term some definite article uses as instances of 'weak familiarity'. In recent years, one senses that such attempts have been given up, and many authors work instead with the idea that there are in fact two types of definiteness in article languages, beginning perhaps with the famous paper by Sebastian Löbner (1985), who distinguishes between semantic and pragmatic definiteness. This view has received strong support from empirical studies of languages with more than one definite article, notably North Frisian (Fering) and some German dialects (Ebert 1971a, Hartmann 1967), and has subsequently been developed into a systematic typology of definites as either strong or weak (Schwarz F. 2009 and later). In his monographic study of definiteness, Christopher Lyons postulates two types of definiteness: textualsituational (including anaphoric and immediate situation uses) and all other uses of the definite article (Lyons C. 1999:198). The most successful of the theoretical proposals in recent years is that of F. Schwarz (2009), whose concept of definiteness builds directly on the familiarity vs. uniqueness opposition. 
Irrespective of the differences between the three proposals, their common denominator is that they do not attempt to reconcile all uses of the definite article under one banner, and that they propose two types of definiteness and not more. Florian Schwarz (2009), whose main inspiration comes from empirical studies of languages with more than one definite article, also acknowledges that we do find contexts in which either of the articles, strong or weak, may be successfully used, revealing that the distinction is not absolute or discrete.

Before we present the current model of the grammaticalization of the definite article, we will first consider a typology of definite article uses. We take the typology proposed by Hawkins (1978) as our point of departure, paying particular attention to the so-called bridging uses of the definite article, in Hawkins' terminology associative anaphora, which we refer to as indirect anaphora. We will then attempt to classify each definite article use as representing definiteness based on either uniqueness or familiarity.

\subsubsection{Types of Reference/Definite Article Use}

In his now classic book on definiteness, Hawkins differentiates between four major uses of the definite article. These are:

1. immediate situation use

2. anaphoric use

3. larger situation use

4. associative anaphoric use

The types may be illustrated by the following examples:

(10) Type 1. the desk (in a room with exactly one desk or accompanied by a pointing gesture)

(11) Type 2. the book (when previous sentence or text included the phrase 'a book' with the same referent)

(12) Type 3. the Queen (in the UK)

(13) Type 4. John bought a book today. The front page was torn. / The author was French.

(after Hawkins 1978 and Schwarz F. 2009)

In the remaining text we will use the following terminology:

Deictical use (Hawkins' type 1) to describe a deictic use of the definite article.

Direct anaphora (Hawkins' type 2) to describe the use of the definite article with a discourse referent previously introduced in the text. 
Indirect anaphora (Hawkins' type 4) to describe the use of the definite article with a discourse referent new in the discourse, but connected to some entity, process or event described earlier in the text. This entity, process or event is termed the anchor (Fraurud 199o).

Larger situation use (Hawkins' type 3 ) to describe the use of the definite article with a discourse referent not introduced previously, directly or indirectly, which the hearer may identify building on his general knowledge.

It is possible to differentiate each type further. Therefore, we will now discuss each type of definite article use in turn.

\subsubsection{Direct Anaphora}

Anaphora is a discourse phenomenon, a relation between two linguistic elements: an antecedent and an anaphor, as in the following example:

(14) I came into a spacious room. It was sparsely decorated and rather gloomy.

A typical antecedent is an indefinite NP, and a typical anaphor is a pronoun or a definite NP. The simplicity of example (14) is of course misleading, for anaphora is a complex linguistic and cognitive phenomenon, which has duly received a great deal of attention, both within linguistic paradigms and in other domains, such as (language) philosophy, psychology, cognitive science and artificial intelligence studies.

In the present study, we differentiate between two very different types of anaphora, which we term direct and indirect. The indirect type corresponds to Hawkins' associative anaphora. The crucial difference between the two is that while both types of anaphora need an antecedent of sorts, the antecedent and the anaphor are co-referring in direct anaphora and not co-referring in indirect anaphora.

In historical linguistics, (direct) anaphora is singled out as the first context of the incipient definite article. Originally a deictic element (see Lyons C. 1999), it begins to be used to point not only in physical context, but also in text (anaphora, see e.g., Anderson and Keenan 1985), which constitutes the first stage of grammaticalization. The use of a demonstrative to point within text involves a shift from situational to textual deixis (Lyons J. 1975). In itself, such use is not sufficient to imply that a grammaticalization of the definite article has begun. This can first be asserted when the original demonstrative comes to be used in the second type of anaphora: indirect anaphora.

Direct anaphoric use includes prototypical examples, such as (15), in which the same discourse referent is described by identical lexical means, but also 
uses such as (16-17), in which the same discourse referent is presented together with some new lexical information.

(15) Fred was discussing an interesting book in his class. I went to discuss the book with him afterwards. (Hawkins 1978:86)

(16) Fred was wearing trousers. The pants had a big patch on them. (Hawkins 1978:107)

(17) Fred bought a new house. The extravagant purchase / This extravagant purchase drained him of all money.

Note that the more new information is added the less natural the definite article becomes. In (17) the demonstrative seems to be a better option (stylistically).

The direct anaphora is based on co-reference of the first and the subsequent mentions of the discourse referent. There is a wide variety of elements which can serve as anaphors and both demonstratives and definite articles can be used anaphorically. However, this interchangeability of demonstratives and articles may be limited by among others stylistic reasons. For more discussion of direct anaphora and its exponents see in particular Kibrik (2011) and Huang (2000).

\subsubsection{Indirect Anaphora}

Indirect anaphora shares some properties both with direct anaphora-its successful resolution relies on information included in the discourse-and also, with larger situation use - the discourse itself does not provide all the information necessary for the successful resolution of the anaphor, which must be supplied by the hearer from their encyclopaedic knowledge. It is a type of reference called bridging reference, understood as a relationship between two objects or events introduced in a text or by a text. The relationship is not spelled out, and yet constitutes an essential part of the content of the text, in the sense that without this information the lack of connection between the objects or events would render the text incoherent (Asher and Lascarides 1998). Let us consider the following examples:

(18) I met two interesting people last night at a party. The woman was a member of Clinton's Cabinet.

(19) In the groups there was one person missing. It was Mary who left. 
(20) John partied all night yesterday. He's going to get drunk again today.

(21) Jack was going to commit suicide. He got a rope.

(22) Jack locked himself out again. He had left his keys on the kitchen table. (examples 18-21 after Asher and Lascarides 1998:83, 22 after Skrzypek 2020)

There is a variety of expressions forming bridging relations with other expressions in the text, including, but not limited to, a definite NP. We can further note that there is some variation as to which form may be used; it would be perfectly possible to substitute a definite article for the possessive pronoun in (22), as well as for the indefinite article in (21), although both substitutions would result in slightly different nuances of the meaning of the NPs.

For the purpose of the present study, we will focus on (nominal) indirect anaphora, the type of bridging that involves anaphoric NPs: examples such as (18), (21) and (22), disregarding other types. It will be of interest to investigate what types of NPs can be used in this context throughout the periods studied, when the definite NPs gain ground, and how their competition against possessive NPs, BNs and other types of NPs plays out.

An unequivocal difference between direct and indirect anaphora is that while the former relies on an antecedent, i.e., a previous mention of the discourse referent, the latter does not. Instead, we are for the most part able to identify some connected entity, event, activity, scenario or frame in the preceding discourse that seems to serve a similar function (two interesting peoplethe woman, suicide - a rope, locked himself out — his keys). This 'antecedent' need not be nominal, thus differing from the antecedent in direct anaphora. In the literature it is referred to as a trigger (Hawkins 1978) or an anchor (Fraurud 1990). In the present study we will use the term anchor to refer to all antecedents of indirect anaphors.

There are a number of possible relations between the anchor and the (indirect) anaphor. The two major types of indirect anaphora are part-whole relations, on the one hand, and semantic roles, on the other. Some authors limit the scope of indirect anaphora to these two (e.g., Irmer 2011), while others identify a third subtype, inferential relations.

(23) a book - the cover (part-whole relation)

(24) a book - the author (semantic roles, nominal anchor) 
(25) to read-the book (semantic roles, non-nominal anchor)

(26) an event—a seemingly unconnected entity, see example (49)

Perhaps the simplest indirect anaphoric relations involve all types of meronymy, i.e., part-whole relations, e.g., watch—battery in example (27).

(27) My watch has stopped. The battery must be dead.

A number of other semantic relations are also possible, such as producerproduct (author-the book), object-component (joke-the punchline), collective-member (deck-the card), mass-portion (pie-the slice), objectmaterial (bike-the steel), activity-episode (shopping — the payment), region-area (Florida - the Everglades). In these types there is a semantic or lexical relation between the anchor and the indirect anaphor, i.e., the knowledge necessary for the resolution of the anaphor is stored in our mental lexicon (Schwarz-Friesel 2007:9).

The meronymic types are further subdivided by Clark (1983) into types describing necessary, probable and inducible parts, as in the following examples.

Necessary parts:

(28) I looked into the room. The ceiling was very high.

(29) I hit a home run. The swing had been a good one.

(30) I looked into the room. The size was overwhelming.

Probable parts:

(31) I walked into the room. The windows looked out to the bay.

(32) I went shopping yesterday. The walk did me good.

(33) I left at 8 p.m. The darkness made me jumpy.

Inducible parts:

(34) I walked into the room. The chandeliers sparkled brightly. 
(35) I went shopping yesterday. The climb did me good.

(36) I left at 8 p.m. The haste was necessary given the circumstances. (Clark 1983, see also Kołaczek 2019)

As the examples quoted indicate, the interpretation of the anaphors, while in each case dependent on the anchor, differs with respect to how natural or stereotypical a part of the aforementioned whole they make.

Another subtype of indirect anaphora is the lexical/thematic type (in Clark's terminology indirect reference by characterisation), which is based on the thematic roles such as instrument, object, agent, etc. The interpretation of indirect anaphors depends on the activation of knowledge in the mental lexicon (Schwarz-Friesel 2007:8). In her extensive study of indirect anaphors in a corpus of authentic texts, M. Schwarz (2000:10of.) presents the following examples to illustrate this subtype:

(37) Nachdem sie das Lokal verlassen hatten, so der Mann, habe die Frau ohne Vorwarnung auf ihn geschossen. Die Pistole habe sie plötzlich aus der Handtasche gezogen.

'After they had left the venue, the man said, the woman had shot at him without any warning. She had suddenly drawn the gun out of her handbag.'

(38) Der Sohn des Englischen Geheimagenten Tarrant wurde entführt. Die Kidnapper fordern ein Lösegeld von einer Million Pfund.

'The son of the English secret agent Tarrant was kidnapped. The kidnappers demand a ransom of one million pounds.'

(39) Er angelte seit Stunden. Aber die Fische wollten und wollten nicht anbeißen.

'He was fishing for hours. But the fish didn't want to take the bait.'

(40) Um sieben Uhr fuhr Tschanz zu Bärlach in den Altenberg [...] Es regnet, und der schnelle Polizeiwagen kam in der Kurve ins Schleudern.

'At seven o'clock Tschanz went to Bärlach in the Altenberg [...] It rains and the fast police car skidded in the curve.'

The roles illustrated by these examples are as follows: in (37) the gun is the instrument of shooting; in (38) the kidnappers are the agents of the action of kidnapping; in (39) the fish is the object of the action of fishing, and in (40) 
the fast police car is the means of transport connected with the action of going somewhere. The common denominator for the examples is a lexical connection between the anchor and the indirect anaphor, e.g., to shoot-a gun. With the lexical/thematic type a more refined categorization is possible, dividing the roles into necessary and optional.

Necessary roles:

(41) John was murdered yesterday. The murderer got away.

(42) I went shopping yesterday. The time I started was 3 p.m.

(43) I trucked the goods to New York. The truck was full.

Optional roles:

(44) John died yesterday. The murderer got away.

(45) John was murdered yesterday. The knife lay nearby.

(46) John went walking at noon. The park was beautiful. (Clark 1983:418)

Clark's classification is basically bi-partite, with parts and roles as the major types of indirect anaphora. M. Schwarz proposes two further subtypes, i.e., scheme-based conceptual types and inference-based conceptual types.

The scheme-based conceptual types are similar to the lexical/thematic type, but as M. Schwarz points out they cannot be interpreted just through the semantic relation (activation of knowledge in the mental lexicon), because the relation between the anaphor and its anchor forms a wider network of associations and connections and involves the processing of the more general world knowledge. Thus, anchors such as restaurant activate a mental frame which includes elements such as waiters, food, menus, bill, as in (47) and (48), and hospital will activate a mental frame with elements such as doctors, nurses, bed, medicine, operating theatre and so on (Schwarz M. 2000:111 ff., Schwarz-Friesel 2007:10).

(47) Ich kenne ein schönes Restaurant in Refrath. Das Essen ist köstlich, und der Kellner ganz besonders nett.

'I know a nice restaurant in Refrath. The food is delicious and the waiter quite especially nice.' (Schwarz M. 2000:111) 
(48) To kill some time I walked over to Greenwich Street, to the Elephant and Castle, $\boldsymbol{a}$ restaurant where my mother and I ate sometimes when we were downtown. But the instant I stepped in, I realized my mistake. The mismatched china elephants, even the ponytailed waitress in a black T-shirt who approached me, smiling: it was too overwhelming, I could see the corner table where my mother and I had eaten lunch the last time we were there, I had to mumble an excuse and back out the door. ${ }^{1}$

The most complex relations are found between anaphors and anchors in indirect anaphors of the inference-based conceptual type. They are typically founded on inferences and deductions and are parts of very specific situations. Therefore, they are most often found in punchlines of jokes (Schwarz M. 200o:114). M. Schwarz illustrates the type by means of the joke quoted below.

(49) Nachts stürzt ein Mann auf die Polizeiwache und berichtet erregt, daß er soeben im Dunkeln an seiner Gartenpforte niedergeschlagen worden sei. Ein Polizist wird beauftragt, am Ort des Überfalls Spuren zu sichern. Kurz darauf kommt er mit einer Riesenbeule am Kopf zurück: „Ich habe den Fall aufgeklärt.“ „Bravo“, sagt sein Chef, „und wie?“” „Ich bin auch auf die Harke getreten!“

'At night a man plunges into the police station and reports with agitation that he has just been knocked down in the dark at his garden gate. One policeman is instructed to secure the scene of the attack. Shortly after he comes back with a huge bump on his head. 'I have solved the case'. 'Bravo' says the chief 'and how?' 'I stepped on the rake, too!' (Schwarz M. 2000:114).

The use of the definite article in the NP 'the rake' is only understandable if we realize that the object is also the 'perpetrator' of the alleged attack on the complainant.

It should be noted that the inference-based conceptual type is not universally regarded as an instance of indirect anaphora; see Irmer (2011). On the other hand, the typology of indirect anaphors as proposed in Clark (1983) may seem too limited, as observed elsewhere.

[W]e remain agnostic as to whether Clark's taxonomy of bridging provides an exhaustive list of plausible bridging relations. There may be rich

1 Tartt, Donna. 2013. The Goldfinch. New York: Little, Brown and Company, Chapter 3, para. xii. 
discourse context in which world knowledge permits a plausible bridging relation that lies outside this taxonomy. (Asher and Lascarides 1998:97)

In the context of the present study, we find that the inference-based conceptual type merits closer scrutiny, as far as this is possible in a historical corpus.

Finally, we should also note that one entity can serve as anchor for a number of different indirect anaphors, also within one text. Consider the following examples:

(50) a. Hanna hat Hans erschossen. Der Knall war bis nach Galdbach zu hören. 'Hanna shot Hans. The report could be heard all the way to Galdbach.'

b. Hanna hat Hans erschossen. Die Wunde blutet furchtbar. 'Hanna shot Hans. The wound is bleeding awfully.'

c. Hanna hat Hans erschossen. Das Motiv war Eifersucht. 'Hanna shot Hans. The motive was jealousy.'

d. Hanna hat Hans erschossen. Die Polizei fand die Waffe im Küchenschrank.

'Hanna shot Hans. The police found the weapon in the kitchen cabinet.' (Schwarz M. 2000:38; she calls the collection of entities and processes activated by the same trigger 'konzeptuell Skopus'.)

Before we continue to discuss other uses of the definite article, we would like to return to some of the first examples of bridging that we quoted in this section, i.e., (18-22). In (22) a possNP was used ('his keys'), in a context in which a defNP would be equally acceptable and correct. It has been observed before that in some uses of the definite article, variation between the article and other items is possible - in direct anaphoric use with a demonstrative, ${ }^{2}$ and in indirect anaphoric use with a possessive.

(51) Beside the barn there is a little cottage. The/This cottage was built in 1875 . (but *Its cottage)

2 This is naturally a simplification. To what extent the demonstratives and the definite article may be interchangeable in a certain context is dependent on a number of factors, including the level of the definite article grammaticalization. Furthermore, proximal and distal demonstratives may behave differently — while in many direct anaphoric contexts the distal demonstrative can be used, the proximal is less felicitous. Consider e.g. the so-called donkey anaphora in English. It is possible to use either the definite article or the distal demonstrative here, e.g. Every farmer who owns a donkey beats the animal/that animal, but Every farmer who owns a donkey beats ${ }^{*}$ this animal (see also Abbott 2002). 
(52) Beside the barn there is a little cottage. The/Its roof is leaking. ${ }^{3}$ (but *This roof) (Skrzypek 2012:45, after Fraurud 2001:246)

However, not all types of indirect anaphora allow this variation freely. In partwhole relations the necessary and probable parts can possibly be expressed by possNPs (compare with examples 28,31 , its ceiling, its windows), but are less acceptable with inducible parts (?its chandeliers, example 34). Lexical/thematic types may allow possNPs occasionally (e.g., his murderer instead of the murderer), but the inferential conceptual types probably never do. Thus, the variation between different $\mathrm{NP}$ types can also be taken as an argument in favour of the proposed taxonomy of indirect anaphors, whose complexity mirrors that of indirect anaphora itself.

\subsubsection{Larger Situation Use}

Larger situation use is the next type of definite article use identified in Hawkins (1978). Similarly to indirect anaphora, in this type of context the hearer must also rely on their encyclopaedic knowledge (specific or general) for a successful resolution of the definite, as in (53).

(53) The Prime Minister has just resigned. (Hawkins 1978:116)

Larger situation uses are different from direct anaphora, which is an immediate situation use, i.e., the referent is then present, though not necessarily visible, in the situation in which the utterance is made. The referent of the direct anaphor may be present physically or mentally, by having been mentioned previously. In larger situation use, on the other hand, people in the same village can talk about the church, the pub, the village green; members of the same nation can talk about the Queen, the navy, the Prime Minister; all people can talk about the sun, the moon, the planets. These larger situations can be of varying size, but they will all have as their focal, defining point the immediate situation of utterance in which the speech act is taking place (Hawkins 1978:115). In this sense the definite article retains its link with the original demonstrative. Depending on the size of the situation, the definite reference may be made based on specific knowledge (we are in a village we know, we know there is a church in it,

3 One reviewer points out that the possessive is a better option, even though the definite article is not incorrect. It seems that for the definite article more context would make it more acceptable, e.g. a sentence 'The cottage is in poor shape' or 'It needs some renovations' before the problem with the roof is presented. 
we can talk about the church), or on general knowledge (we do not know the church, but it is part of our knowledge that there usually is one in a village). This context may allow determiners other than the definite article, especially possessives; however, the variation is limited to some sub-types (especially to larger situation uses based on specific rather than general knowledge, e.g., our Prime Minister, ourvillage pub) and it may be subject to stylistic considerations.

Larger situation use is entirely dependent on the size of the situation and may be crudely subdivided into local and global larger situation uses, which form a continuum rather than discrete categories. In examples (54-58), we can discern how the utterance situation gradually becomes larger: from a very local one (a room), in which the definite the sofa does not preclude that there are other sofas in rooms nearby, to the most global one, comprising the whole world, which has only one sun.

(54) the sofa (in a room)

(55) the kitchen (in a flat)

(56) the church (in a village)

(57) the King (in a kingdom)

(58) the sun (in our solar system)

It is not a coincidence that the different definite article uses have been presented in this order. We may observe how the different types of definite article use overlap: indirect anaphora seems to be located in between direct anaphora and larger situation use, sharing some features with both. On the one hand, it is anchored in the text, just as direct anaphora is; on the other, it relies on some knowledge from outside the text, as larger situation uses do. We may also conclude that some types of direct anaphora resemble indirect anaphora in this respect, i.e., even though the discourse referent is the same, it is presented by means of a new, or more detailed description, e.g., a book-the magnificent volume and not by mere repetition as in a book- the book. To successfully understand this, the hearer must be able to equate the volume with the book. Also, since indirect anaphors may be anchored in the text by means of other elements than just nominal ones, even genres themselves, one could extend the notion of context to include the (physical) context of the utterance, e.g., a conversation taking place in a courthouse, where the use of the defNP the judge would be entirely natural. Let us imagine a person entering the courthouse and 
being greeted by the phrase Welcome to the courthouse. The judge will see you shortly, or by the phrase Good day. The judge will see you shortly. If we are rigorous, we would need to classify the two uses as two different types of definite article use: indirect anaphora in the first example (with a definite anchor the courthouse) and larger situation use in the second (as there is no anchor in the text, the definiteness is a result of the situation of the utterance, i.e., being in a courthouse).

The model of definite article grammaticalization proposed in the literature stipulates that the incipient definite article will begin with direct anaphoric use and gradually spread through indirect anaphora to larger situation use. Before we discuss the model in detail, we will present the common sources of definite articles and main differences between definite articles and demonstratives.

\subsubsection{The Etymology of the Definite Article}

The origins of the definite article lie in deictic elements, most typically in demonstrative pronouns. This applies to Germanic languages, such as English (the), German (der) and Swedish (the clitic -in, stemming from demonstrative hinn 'yon'), Romance languages (French le/la, Italian il/la, Spanish $e / / l a$, Portuguese $o / a$ are descendants of Latin ille 'that'), and Slavic languages (the Bulgarian clitic article - $t a$ from demonstrative $t a$ 'this'), but also to non-IndoEuropean languages such as Bizkaian Basque $a$ or Hungarian $a z$ (Heine and Kuteva 2002:109-110). In his discussion of the sources of the definite article, C. Lyons (1999) demonstrates that in languages where the definite originates in an element different from a demonstrative it can still be regarded as deictic, similar to the verb behold in contexts such as Behold the Walls of Moria, which can correspond to Latin ecce or Slavic oto (Lyons C. 1999:331 quotes the definite article in Sissala as originating in a verb of a similar meaning). Heine and Kuteva (2002:110) establish demonstratives as the major source of definite articles.

Even though the deictic origin of the definite article seems nigh on universal, Fraurud (2001) demonstrates how definites can develop out of possessive pronouns, discussing Uralic languages as an example of such a process. It should be noted, as Fraurud herself observes, that the scope of the use of the articles which have arisen out of deictic and possessive elements is not identical. Similar ideas are found in Bechert (1993):

[...] in this continuum (between the possessive and the emerging definite article-DS), the end seems to be never reached, at the eastern margins of Europe and in Northern Asia, the definite article remains a category in statu nascendi. It might even be the case that this category in Eurasian 
languages is a product of our Eurocentric perspective. If we reverse the perspective, we can view the European category of the definite article as a special case of a category of belonging which is denoted indirectly, in Europe, by weakened demonstratives and would be more aptly expressed by possessive suffixes, as it is in Northern Asia and its western outskirts. (Bechert 1993:37 f.)

In the case of the North Germanic languages the source of the definite is deictic and the model of grammaticalization has a demonstrative as its source. ${ }^{4} \mathrm{We}$ will therefore concentrate on the potential of the demonstrative to grammaticalize into a definite article.

\subsubsection{Demonstratives vs. Articles}

One of the fundamental properties of articles is the necessity of their use. In an article language, such as English, it is only in a limited number of contexts that one may omit the article and use a bare noun instead. There is, however, a certain degree of variation, which allows the speaker to use a different determiner instead, e.g., a possessive or a demonstrative pronoun in place of a definite article, as we have illustrated in discussion of different definite article uses, in particular indirect anaphora. Two examples can be quoted after Fraurud (2001) (with modifications).

(59) We came to a little village. This/*Its/The village was underpopulated. *This/Its/The church was old. *This/"Its/The sun was shining.

There are three types of reference in this brief story: a direct anaphoric reference (a village - the village) and an indirect anaphoric reference (avillage - the church), both textually founded, and a unique reference (the sun), whose definiteness is independent of the previous discourse. In each type the definite article can be used, and is perhaps the preferred option. If it is not used it can be exchanged for a demonstrative in direct anaphoric reference or a possessive in indirect anaphoric reference; none of these will work, however, with unique reference. Therefore, there does seem to exist a difference between the demonstrative, in which the definite article originates, and the definite article itself. This difference, however, is not clear-cut, and therefore the stages of

4 It should be noted that some scholars have considered an alternative source of the definite article in personal pronoun han 'he' (Gjerdman 1924; Perridon 1996). This idea has not won support. 
grammaticalization are not discrete. In other words, the development forms a continuum from a purely deictic element to a distinct definite article. The grammaticalizing entity gradually turns into an article; we expect to find that at some point in the course of this process it may exhibit features of both the demonstrative and the article. It is therefore important to define what these features may be in order to classify the form found in the texts as either one or the other, or perhaps as the incipient article.

In many languages demonstratives form a complex group of entities, which among others differ with respect to the distance from the speaker that they encode. While a demonstrative is usually regarded as a linguistic counterpart of a pointing gesture, there may be additional information on the location of the referent pointed at, such as its proximity to the speaker (e.g., English this) or its remoteness from the speaker and possibly also the hearer (e.g., English that). No such information is conveyed by means of the definite article; therefore, the loss of such a distinction is regarded as one of the first hallmarks of grammaticalization, even though the distinctions may persist for some time (Lyons C. 1999:55).

From the examples quoted above we may further note that the demonstrative is not allowed in a number of contexts in which the definite article is the default option. These include generic reference (not mentioned above, but easily illustrated with sentences such as The/*This/*That lion is a mammal) and unique reference (which Hawkins 1978 calls larger situation use, in which no textual context is necessary to make the definite form, and the identification of the referent, felicitous), but also indirect anaphora, which we believe to be of crucial importance in the development of definiteness marking.

Finally, it should be noted that there may be differences among demonstratives themselves. In English, for instance, in some contexts the distal that is allowed while the proximal this is not, e.g., That/The/*This hominid who discovered fire was a genius (King 2001). As one reviewer points out, a similar pattern can be found in Icelandic in which the proximal peessi cannot be used, but a non-proximal sá can.

\subsubsection{From a Demonstrative to a Definite Article}

The most commonly identified first stage in definite article grammaticalization is the use of the form in direct anaphoric contexts (see in particular Lyons J. 1975, also Diessel 1999). At this stage, the deictic use of the demonstrative is extended to include textual, and not only situational deixis. In many languages that have not developed articles, such use of demonstratives is perfectly normal without its grammaticalizing into the definite article (see also Chapter 5). C. Lyons notes that in anaphoric contexts either proximal or distal demon- 
stratives can be used (if both are available) with no apparent difference in meaning (see also De Mulder and Carlier 2011:526). Thus, the semantic difference between them is blurred, which is the first step in the grammaticalization process.

It has been observed, however, mainly through empirical studies on Romance languages (Epstein 1993 on Old French, Selig 1992, Vincent 1997 and Carlier and De Mulder 2010 on Late Latin, and Faingold 2003 on the evolution from Latin to Spanish, Portuguese and Romanian), that the anaphoric use of demonstratives is originally not neutral, but involves topicalized or focused discourse referents, usually highly individuated, typically human and agentive.

The next, highly debated, stage of definite article grammaticalization is the use of the incipient article in indirect anaphoric contexts. This is the use typical of a definite article, in which no variation with the demonstrative is possible. The definite article's function in this context is to instruct the hearer to retrieve the discourse referent indirectly, i.e., via its anchor (see 2.2). This is the crucial shift in the use of the original demonstrative (or other deictic element) and has so far not been fully accounted for (see also De Mulder and Carlier 2011:527).

The final stage of grammaticalization of the definite article is its appearance in larger situation use, including the most global uses, such as the sun. In contrast to the previous two stages, this stage is characterized by the fact that the definite article is used independently of the textual information. There is no antecedent or anchor, nothing to ground the discourse referent in the text; the definite form may be used out of the blue, so to speak.

The development described above can also be formulated in terms of types of context, according to Heine (2002). Heine (also Diewald 2002 and 2006, although in different terms) describes the new contexts acquired by the grammaticalizing form in terms of their connection with the form's original meaning. Heine focuses on the affinity in meaning between consecutive forms as the grammaticalization proceeds. Reflexes of the original semantics are present in the fully grammaticalized form, allowing its use in the original contexts, such as those of a future marker formed from the verbs 'to wish' or 'to want', although in some grammaticalizations this connection may be severed, as with the negation marker in French. Heine argues that there are two meanings available for the form in the stages of grammaticalization which he terms bridging and switch contexts: as the source and as the target.

- bridging contexts: trigger an inferential mechanism to the effect that, rather than the source meaning, there is another meaning, the target meaning; it is most likely to be inferred but is cancellable (Grice 1967) which means that an interpretation in terms of the source meaning cannot be ruled out; a given linguistic form may be associated with a number of contexts. 
- switch contexts: incompatible or in conflict with some salient property of the source meaning; interpretation in terms of the source meaning is ruled out; the target meaning provides the only possible interpretation.

- conventionalization: meanings that need no contextual support, turn into 'normal', 'inherent', 'usual' or 'semantic' meanings. That a target meaning has been conventionalized may be seen when it can be used in new contexts, other than bridging or switch, which may violate the source semantics. (Heine 2002:84-85)

In Table 4 we present a model of grammaticalization of the definite article formulated in terms of Heine's context typology.

It should also be noted that the grammaticalization of the definite article may proceed beyond the final stage identified here, when the definite article turns into a specificity marker, from where it may proceed even further to noun marker and primary exponent of the category gender, as in (6o) (as first proposed by Greenberg 1978, note that the stages in Table 4 and (6o) do not match as two different models are discussed here).

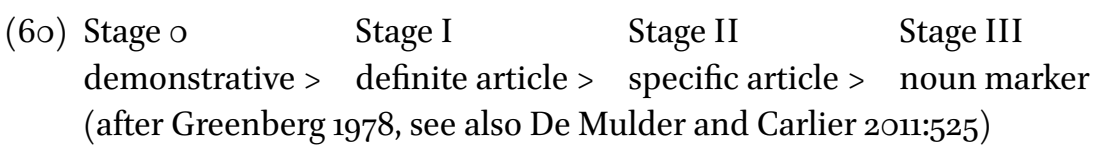

Greenberg (1991) observes that the development is more likely to proceed to stage II and beyond in a language that has no indefinite article (Greenberg 1991, cf. De Mulder and Carlier 2011:525). This observation merits its own study. Here we may note that if there is an indefinite (or an incipient indefinite) article in a language with a definite article, the two forms will be in competition in contexts based on specificity. Conversely, in absence of an indefinite article, the definite may come to be used with specific (not necessarily definite) reference and thus proceed to Greenberg's Stage II of the grammaticalization.

The implicit conclusion of the model is that articles may be lost as well as formed. The model does not predict the definite article turning into morphological zero, but rather illustrates that the expansion beyond Stage I and especially beyond Stage II entails the article acquiring non-definite uses, and thus becoming something other than a definite article (Lyons C. 1999:337). Such development is attested in Voltaic languages Gurma and Gangam and in Eastern Aramaic. Greenberg's model finds support in Schuh (1983), a study of the development of the definite determiners in the Chadic languages. Schuh notes that a form that was once the definite article in some dialects of Bade is now found in contexts in which it can only be interpreted as signalling indefinite- 
TABLE 4 Stages and contexts in the grammaticalization of the definite article (after Skrzypek 2012:49)

\begin{tabular}{|c|c|c|}
\hline $\begin{array}{l}\text { Stage in } \\
\text { grammaticalization }\end{array}$ & Context & $\begin{array}{l}\text { Demonstrative/definite } \\
\text { article-function }\end{array}$ \\
\hline Stage I & Original context & Deixis \\
\hline Stage II & Bridging context & Direct anaphora (textual deixis) \\
\hline Stage III & $\begin{array}{l}\text { Bridging context/ } \\
\text { Switch context }\end{array}$ & Indirect anaphora (textual) \\
\hline Stage IV & Extended switch context & Unique reference (non-textual) \\
\hline Stage V & Conventionalization & Generics (non-textual) \\
\hline
\end{tabular}

ness. Greenberg's model presents the development as potentially cyclical (see also van Gelderen 2007). ${ }^{5}$

The model takes a deictic element as its starting point. As noted above, there has been some evidence of possessives grammaticalizing into definite articles, e.g., in Bantu and Oceanic languages (see also Bechert 1993). However, the possessives never seem to reach the full range of definite uses associated with definite articles with deictic sources. The model still leaves a number of questions unanswered, in particular the switch from direct to indirect anaphora and from indirect anaphora to larger situation use. We will consider these questions on the basis of North Germanic data in Chapter 5 .

Finally, empirical studies of article languages have revealed that in languages with two definite articles (such as some German dialects or Fering; see 2.4), their scope of use differs in that one definite article is used with direct anaphora and the other with referents in larger situation use, with indirect anaphors represented by either (but not necessarily in free variation). This fact would suggest that in some languages the grammaticalization process may involve more than one item at a time, resulting in a system with two definite articles, while in other languages one grammaticalizing item covers all uses, both

5 As one reviewer points out, given the long history of human language it is unlikely that the emergence of (definite) articles is merely a recent development; on the contrary, we may assume that over the course of human (language) history, articles have emerged many times without leaving traces until writing made it possible to document these developments. On the other hand, the interdependencies between articles and literacy merit a separate (diachronic) study. 
corresponding to weak and to strong definite article. We will consider this hypothesis in the next section.

\subsubsection{The Meaning of Definiteness}

The discussion of the gradual spread of the incipient definite article to new contexts can be founded on the concepts of familiarity and uniqueness, which we will briefly present here. It is a part of the discussion of the meaning of definiteness, which dates back at least to Frege's (1892) classic example The Morning Star is the Evening Star, has mainly focused on why some discourse referents may be definite, with two major concepts emerging: the discourse referents are definite either because they are familiar or because they are unique. A number of attempts have been made either to subsume all uses of the definite article under one or the other (e.g., Christophersen 1939 opts for familiarity in all definite article uses) or to reconcile the notions by widening the scope of their meaning, as in weak familiarity (Roberts 2003). A common denominator for most theoretical literature on definite descriptions has been an explicit goal of providing a universal analysis of all types of their uses in natural languages. Empirical studies, on the other hand, have provided linguists with new insights into the meaning of definiteness. With the benefit of field studies of languages with more than one definite article, a number of authors have suggested that the two notions cannot be reconciled and that there are instead two types of definiteness: expressed by weak and strong definite articles (roughly corresponding to the original uniqueness and familiarity respectively), in terms proposed in particular by F. Schwarz (2009) and developed in his later publications. Essentially, strong definite articles are based on familiarity and the typical use of a strong definite article is direct anaphora, while weak definite articles are based on uniqueness, and are used with uniquely identifiable referents, e.g., in larger situation uses. The dichotomy is reflected in some languages with two definite articles that are in complementary distribution in certain contexts, e.g., the Fering dialect described in Ebert (1971a) (see examples in 61 below) and a number of German dialects, such as the dialects of the Rhineland (Heinrichs 1954), the Mönchen-Gladbach dialect (Hartmann 1982), the Cologne dialect (Himmelmann 1997) and Bavarian (Scheutz 1988, Schwager 2007). Since some languages have developed two semantically different definite articles, perhaps the notion of a unified account should be abandoned - this is the position taken in a growing body of literature on definiteness.

\subsubsection{Definite Articles in Fering and German}

Fering is one of the first languages with two definite articles for which different patterns of their distribution were observed and analysed. A number of 
TABLE 5 The definite article paradigms in Fering (Ebert 1971b:159)

$\begin{array}{lllll}\text { Article form } & \text { M.SG F.SG N.SG PL }\end{array}$

$\begin{array}{lllll}\text { A-form (weak article) } & \text { a } & \text { at } & \text { at } & \text { a } \\ \text { D-form (strong article) } & \text { di } & \operatorname{det}(\text { jü) } & \text { det } & \text { dön (dö) }\end{array}$

German dialects share the same pattern, and Standard German exhibits an interesting variation in the use of the definite article in its full or contracted form (after a preposition). This variation is the cornerstone of the weak-strong definite semantics hypothesis (Schwarz F. 2009), which will be the subject of the following section. Here, we will briefly discuss the article system in Fering and the German variation.

In Table 5 the definite article paradigms in Fering are presented, followed by some examples of their use. Both articles are descendants of demonstratives, $d i$ is cognate with the North Germanic den, English the and $a$ are most likely cognates of North Germanic inn and English yon 'that' from Proto-Germanic *jaino-.

Fering (Ebert 1971b:161)

(61) a. Ik skal deel tu a / *di kuupmaan.

I must down to DEF.WK / DEF.ST grocer

'I have to go down to the grocer.'

b. Oki hee an hingst keeft. ${ }^{*} A / D i \quad$ hingst haaltet

Oki has INDF horse bought DEF.WK/DEF.ST horse limps 'Oki has bought a horse. The horse limps.'

The same distributional restrictions apply to the definite article in German when it is a part of a prepositional object (Hartmann 1980, Schwarz F. 2009). The article is used in its full form in phrases with familiar reference, and in a contracted form in phrases with unique reference.

(62) Hans ging zum Haus.

Hans went to.DEF.wK house

'Hans went to the house.'

(63) Hans ging zu dem Haus.

Hans went to DEF.ST house

'Hans went to the house.' (Schwarz F. 2009:7) 
Even when both articles can seemingly be used, there is a difference in meaning, or more specifically, in the reason for the definiteness of the NP. Consider the two examples given in Ebert (1971a).

\section{Ebert example 38 a}

(64) A hunj hee tuswark.

DEF.WK dog has toothache

'The dog has a toothache.'

Ebert example $38 b$

(65) Di hunj hee tuswark.

DEF.ST dog has toothache

'The dog has a toothache.' (Ebert 1971a:83)

Beide Äußerungen setzen voraus, daß der Hörer bereits weiß, welcher Hund gemeint ist. Die Voraussetzungen sind aber für [(38a)] und [(38b)] verschiedener Art. [(38b)] ist eine adäquäte Äußerung, wenn der Hund im vorhergehenden Text speziziert wurde; der D-Artikel weist dann anaphorisch auf den Textreferenten. [(38a)] setzt voraus, daß der gemeinte Hund nicht näher spezifiziert zu werden braucht, weil zur Zeit und am Ort des Sprechaktes nur ein einziger Hund als Referent in Frage kommt.

Both utterances presuppose that the hearer already knows which dog is meant. But the presuppositions (for the two forms) are of a different nature. $[(38 b)]$ is an adequate utterance if the dog was specified in the preceding text; the (strong; FS) D-article then refers anaphorically to the text referent. [(38a)] presupposes that the intended dog does not need to be specified any further, because there is only one dog at the time and place of the speech act that could be meant. (Ebert 1971a:83, translation Schwarz F. 2009:38)

This is not to say that the two articles are in complementary distribution. The two articles are interchangeable in some contexts. F. Schwarz (2009) quotes examples of weak definite articles used in direct anaphoric contexts.

(66) Meyer har sich ein Haus mit Garten gekauft. Im Haus Meyer has REFL INDF house with yard bought in.THE.WK house selber halt sich Meyer tagsüber nur selten auf. Er arbeitet itself stays REFL Meyer during.the.day just rarely on he works 
gerne im Garten.

happily in.the.wn yard

'Meyer has bought a house with a yard. He rarely stays in the house in the daytime. He likes to work in the yard.' (Hartmann 1978:78, quoted after Schwarz F. 2009:44)

(67) Der Gaustadvatnet ist ein See in Norwegen. Am See liegt DEF Gaustadvatnet is INDF lake in Norway on.the.wK lake lies der Ort Korsvegen DEF town Korsvegen

'The Gaustadvatnet is a lake in Norway. The town Korsvegen lies on the lake.' (http://de.wikipedia.org/wiki/Gaustadvatnet, quoted after Schwarz F. 2009:44)

The same example retrieved in 2020 shows the referent of am See introduced not as a predicative but as a modifier, though this is not likely to have influenced the choice of form.

(68) Gaustadvatnet [...] ist der Name eine-s See-s in Norwegen. Gaustadvatnet is DEF name INDF-GEN lake-GEN in Norway Am See liegt der Ort Korsvegen. on.the.wK lake lies DEF town Korsvegen 'Gaustadvatnet is the name of a lake in Norway. The town Korsvegen lies on the lake.'

Familiarity as a basis of definiteness builds on the insight that the speakers use definite descriptions to refer to discourse referents that are in some way known to the hearer, because they have either been mentioned before or are visible to the hearer (or at least present in the context of the utterance). Uniqueness, on the other hand, stresses that speakers may use definite descriptions that have not been mentioned earlier and are not visible or present in the immediate utterance situation, but can be identified by the hearer because they have a role or property that is unique (at least within some domain). It is of course possible that a referent is both present in the immediate situation and is one of a kind.

However, uniqueness must have some reference frame. Is the referent unique in the whole universe? On the continent? In the country? In our town? In our apartment? The fact that sentences like The couch needs to be cleaned are felicitous despite there being hundreds of thousands of couches demonstrates that either the definite descriptions are incomplete (and the missing 
content must be supplied by the hearer) or that the uniqueness is not absolute, but the referent may be unique with respect to some domain only. This is consistent with Hawkins' larger situation use in its local version. Similarly, familiarity has also been nuanced, differentiating between strong and weak familiarity (Roberts 2003), with the former consistent with the referent being used anaphorically, and the latter with the referent being familiar by virtue of 'being perpetually accessible to the discourse participants' (after Schwarz F. 2009:3).

\subsubsection{The Problem of Indirect Anaphora}

While it has been relatively easy to map two uses of the definite articledirect anaphora and larger situation use-onto the strong-weak (or familiarunique) distinction, it is not as easy to do so with indirect anaphoric use. Turning once again to a language with two distinct definite articles, Fering, we note that this use can be represented by either of the articles.

Fering (Ebert 1971a:118, after Schwarz F. 20o9:62)

(69) Wi foon a sark un a maden faan't taarep. A

We found DEF church in DEF middle of.the village DEF.WK

törem stän wat skiaf

Tower stood a little crooked

'We found the church in the middle of the village. The tower was a little crooked.'

Fering (after Schwarz F. 2009:62)

(70) Peetji hee uun Hamboreg an bilj keeft. Di mooler hee Peter has in Hamburg INDF painting bought DEF.ST painter has ham an guden pris maaget.

him INDF good price made.

'Peter bought a painting in Hamburg. The painter made him a good deal.'

This type of definite article use cannot be easily classified as either weak or strong, as its use is in fact based on both familiarity (by virtue of the definite being anchored in previous discourse) and general knowledge. Furthermore, there are a number of ways to anchor a referent and a number of semantic relations between the anchor and the indirect anaphor. On the basis of the Fering data and his own questionnaire, F. Schwarz finds that the type of indirect anaphora which involves part-whole relations is realized by strong definites, while the type which involves semantic relations such as product-producer is realized by weak ones (Schwarz F. 2009). 
Finally, a few words on the definite reference and the concept of totality. The motivation (of the speaker) for using definite description is one matter; another is the effect the definite description has on the hearer. A phenomenon that has been widely discussed in the literature, both linguistic and philosophical, is the so-called uniqueness effect. On hearing a definite description, the hearer will automatically assume that there is only one referent of that description, whether known or unknown to the hearer. With plural or mass referents, the hearer will interpret the definite description so that it corresponds to 'all of', giving a sense of completeness, Hawkins' totality, as exemplified in the quote below.

Consider the following data.

3.172 Bring the wickets in after the game of cricket.

Would I be satisfied if the hearer brought me only four or five of the six wickets? I would not. The wickets refers to all six.

3.173 I must ask you to move the sand from my gateway.

Would I be satisfied if only some were moved? As before, I would not. If my hearer only moved part of the sand away I would be justified in complaining: I thought I asked you to. (Hawkins 1978:159)

Observe that the uniqueness-effect with singular count nouns limits the potential discourse referents to one. In this, we find a parallel with the origins of the indefinite article, which are invariably found in numeral 'one'. As we will argue below, the grammaticalization of the indefinite article at its early stages mirrors that of the definite article. Here we may find a clue to the puzzle of universality of sources we named in Chapter 1. The definite article emphasizes the singularity of the discourse referent and the indefinite article, at the early stages of grammaticalization, also states that there is one discourse referent, of which more will be said (see 5.4.1).

\subsubsection{Grammaticalization of the Definite Article and Strong-Weak Definite Article Semantics}

The strong-weak dichotomy has consequences for the diachronic account of definite article grammaticalization. As we have noted above, in languages with two definite articles which are used in different contexts, we may assume that the process of grammaticalization consists of two sub-processes, each concerning one form, which are mutually interdependent and which influence each 
TABLE 6 The suggested global cycle of definite articles (Carlier and Simonenko 2016:10)

\section{Late Latin Old French Preclassical French Modern French}

$\begin{array}{lllll}\text { Direct anaphora } & \text { ille } & \text { li } & \text { le } & \text { ce } \\ \text { Relative clauses } & \text { ille } & \text { li } & \text { le } & \text { le/ce } \\ \text { Relational nouns } & \text { o } & \text { li } & \text { le } & \text { le } \\ \text { Mass nouns } & \text { o } & \text { o } & \text { le } & \text { le } \\ \text { Abstract nouns } & \text { o } & \text { o } & \text { le } & \text { le }\end{array}$

other resulting in a system such as for example the Fering one, in which two definite articles are used differently. ${ }^{6}$ However, in the languages included in the present study one definite article has emerged, whose use encompasses both those based on familiarity and on uniqueness. ${ }^{7}$ Part of the grammaticalization process is, therefore, the shift of the incipient definite article from strong to weak semantics.

In their 2016 work, Carlier and Simonenko test this hypothesis for the Old French definite article, suggesting that while strong definite semantics include the requirement that there be a salient individual in a given situation, the requirement for weak definite semantics is that there be a unique, not necessarily salient, individual in a given situation.

With a change from strong to weak semantics, the l-forms are expected to expand onto the contexts typically satisfying the uniqueness/maximality presupposition and previously left to the zero article. (Carlier and Simonenko 2016)

The passage from strong to weak definite semantics in the history of the French definite article was shown in the distribution of the forms to be compatible with this hypothesis.

6 In the case of North Germanic, Dahl (2004:178) argues that there are in fact two separate grammaticalization processes.

7 It could be claimed that there are in fact two distinct definite articles, at least in the Mainland languages in the sample, Danish and Swedish, den and -en, with different etymologies and position in the NP. However, their distribution is not dependent on the type of discourse reference as is the case in Fering (see also Chapter 1 for an overview of definite article distribution). Nevertheless, some authors (notably Julien (2005) and Lohrmann (2010)) argue that they do encode different referential properties (e.g. discourse reference vs. specificity). 
The authors include an intuitive interpretation of the etymology of the definite typically lying in the distal (and not proximal) demonstrative, as this fact seems to allow the hearer to draw on some additional descriptive content in order to retrieve a referent normally not present in the physical context of the utterance (ibid., compare also De Mulder and Carlier 2011).

\subsubsection{Final Stages of the Grammaticalization of the Definite Article}

As the original demonstrative gradually loses some of its semantic and phonological content and moves towards the definite article, gaining new functions, it appears in more and more contexts that are not accessible to demonstratives proper, such as (some types of) indirect anaphora and larger situation uses. Gradually it forces out potential competitors, such as possessive pronouns and bare nouns, to become the only 'correct' form to be used in these contexts. We argue, alongside many other scholars of grammaticalization, that although the grammaticalization cline is a universal model, i.e., the development in unrelated languages proceeds through the same or at least similar stages, different languages may develop definite articles to varying degrees. In other words, the grammaticalization may halt at any point. Therefore, there are languages with definite articles that are, for instance, only used with direct anaphoric reference. It is also common for a language to have a definite article that is not used with generic reference.

Generics are notoriously difficult to describe in terms of form. Many article languages allow great formal variation in this type of reference; in North Germanic five different forms may be used: bare noun singular, definite singular, definite plural, indefinite singular, bare plural. Although all five forms are allowed (except in Icelandic, which does not have an indefinite article), they are not fully interchangeable; at times one or two forms are preferred over the other three or four. The factors behind the choice of one form rather than another are understudied, although it seems that both animacy and countability of the referent play an important role (see also Pettersson 1976, Carlsson 2012 for Swedish, Kurek-Przybilski 2020 for Norwegian, Skrzypek and Kurek 2018, Skrzypek, Kurek-Przybilski and Piotrowska 2020 for a comparison between the Continental North Germanic languages). We may therefore conclude that the grammaticalization of both the definite and the indefinite articles has not reached the stage in which one or the other is considered to be a generic marker, which is a relatively common property of articles in all of the Germanic languages. 


\subsection{The Rise of the Indefinite Article}

In 2.2.5 (The meaning of definiteness) we have noted that the variety of uses of the definite article has led to numerous efforts to explain the seeming disparity in the meaning of definiteness. We have also chosen to follow F. Schwarz in his strong-weak dichotomy. The meaning of indefiniteness does not seem to have generated similar debates. However, it has been recognized that the indefinite article can be used in two types of contexts: specific and non-specific. ${ }^{8}$

\subsubsection{Types of Indefinite Article Use}

Specificity is the traditional heading under which specific and non-specific uses of the indefinite article are discussed. The difference between them can be illustrated by the following examples:

(71) I bought a car this morning.

(72) Pass me a book.

Neither of the referents is identifiable to the hearer, but in the first example the speaker is familiar with it, the referent is specific, while in the second, neither the hearer nor the speaker is familiar with the referent of the indefinite NP a book (Lyons C. 1999:165). This double nature of the indefinite article is also known as referential opacity (Quine 1940, 1953). In its specific uses, the indefinite article is referentially transparent; in others it is referentially opaque and requires more context to be interpreted as either specific (74a) or non-specific (74b).

(73) John married a rich woman.

(74) John wanted to marry a rich woman,

a. ... but she refused him.

b. ... but he couldn't find any. (Quine 1953, quoted after Skrzypek 2012:51)

8 One reviewer points out that the uses of the indefinite article could be divided into more subtypes. Haspelmath (1997) distinguishes three types, i.e. non-specific (She wanted something to eat), specific unknown (She got something to eat (I don't know what it was.)) and specific known (She got something for her birthday. (Canyou guess what it was?)). These subtypes may have separate morphological representations. In the present study we limit the classification to specific vs. non-specific uses of the indefinite article. 
The opacity is created by a logical operator, such as negation. A number of other contexts render the indefinite opaque, such as conditionals, verbs of volition and propositional attitude, questions, modals and future tense.

\subsubsection{From a Numeral 'One' to an Indefinite Article}

A model of indefinite article grammaticalization was proposed by Givón (1981). We begin with a more detailed model proposed by Heine (1997).

The first stage of the grammaticalization of the indefinite article is the so-called presentative use of the incipient indefinite article. In this use the numeral 'one' serves as a presentation marker for a new discourse referent, which is salient in the discourse. In discussions of indefinite article grammaticalization this use is often likened to the use of the proximal demonstrative 'this' in English, studied in Prince (1981a, 1981b).

(75) This man came and wanted to speak to the manager.

What is characteristic for this use is that it raises the hearer's expectations with regard to the new discourse referent, and the hearer is expecting to hear more about it, since it has been marked as salient. This use of the incipient indefinite article is limited to introducing most important discourse referents, to which further reference will be made. As the first article-like use of the demonstrative was anaphoric, this first article-like use of the numeral is in a sense cataphoric.

It should be noted that at this stage there may be a number of competing forms, i.e., other presentative markers in use in the language, such as indefinite pronouns like 'some', 'any' or adjectives like 'certain', but invariably it is the numeral that grammaticalizes into the indefinite article (see, e.g., an interesting study of Old Tuscan by Stark 2002, who studied the competing forms at the onset of article grammaticalization).

In spoken discourse any ambiguity in interpretation between the numeral and the presentative and specific markers is often resolved by the presence or absence of stress. In diachronic studies no such disambiguation is possible; however, other tests are available. Previous studies of indefinite article grammaticalization in Swedish reveal that, at the onset of the grammaticalization, the original numeral 'one' is used with new discourse referents which are picked up by at least one anaphoric expression (Skrzypek 2012, 2013). There is a tendency to place them clause-initially (stylistically indefinites are not preferred in initial position in modern Swedish); they are also predominantly subjects. However, this may be a language-specific idiosyncrasy.

The second stage of indefinite article grammaticalization is the use of the incipient article with all new discourse referents, irrespective of their salience. 
In this use we find also backgrounded referents introduced as indefNPs, referents which are mentioned only once in the text and to which no anaphoric reference is made. The presentative marker is in fact a subtype of the specific marker, as it is also used to introduce new referents into the discourse. However, any competing forms appear only at the presentative stage. Hopper and Martin (1987), in a study of the rise of the indefinite article in Old English, note that there is some variation in this context between the numeral an and sum and that the variation seems to be quite systematic: while sum introduces new and salient referents with numerous subsequent mentions and is located at the beginning of the text, an introduces less salient referents with fewer subsequent mentions and can appear anywhere in the text, not just at the beginning. Both uses fall under the category of the specific use of the indefinite article. The development beyond this stage involves the use of the incipient indefinite article also in non-specific contexts, such as in questions and conditionals and under the scope of negation, verbs of volition and verbs of propositional attitude.

The final stage of indefinite article grammaticalization is the use of the original numeral 'one' in generic NPs.

(76) Model of grammaticalization of the indefinite article according to Heine (1997:72-73)

Stage I: the numeral 'one'

Stage II: presentative marker

Stage III: specific marker

Stage IV: nonspecific marker

Stage V: generalized article

As with the definite article, we place the consecutive stages of grammaticalization in Heine's typology of context (Heine 2002); see Table 7.

The final stage of indefinite article grammaticalization, the generalized article, is in fact identical with the final stage of the definite article grammaticalization, i.e., the article can be used generically.

\subsection{Previous Studies on the Grammaticalization of the Definite Article in North Germanic}

The rise of articles in North Germanic, in particular that of the definite article, has been the subject of a number of studies using different theoretical approaches. It is not realistic to do all of them justice; nevertheless, in 
TABLE 7 Stages and contexts in the grammaticalization of the indefinite article (after Skrzypek 2012:53)

\begin{tabular}{lll}
$\begin{array}{l}\text { Stage in } \\
\text { grammaticalization }\end{array}$ & Context & Numeral 'one'/indefinite article \\
\hline Stage I & Original context & Numeral \\
Stage II & Bridging context & Presentation marker \\
Stage III & Bridging context/ & Marker of specific reference \\
& Switch context & \\
Stage IV & Extended switch context & Marker of non-specific reference \\
Stage V & Conventionalization & Generalized article \\
\hline
\end{tabular}

this section we present a brief overview of selected publications that have either influenced a number of scholars or have a direct bearing on the present study.

\subsubsection{General Studies}

The subject of the evolution of the definite article in North Germanic has attracted much attention. The structure of the defNP in modern North Germanic languages mirrors three layers of linguistic innovation: the grammaticalization of the weak adjectival declension (the origins of which most likely are to be found in a coalescence of the adjective with an original demonstrative particle, e.g., Heinrichs 1954:67), the grammaticalization of the postposed, suffixed definite article, and the grammaticalization of the preposed definite article. The origins of each process are found in the extended use of demonstratives.

The formation of the weak adjectival declension belongs to the ProtoGermanic period (Prokosch 1939, Ringe 2006) and is common to all Germanic languages, as well as some Baltic and Slavic ones. It has been studied mainly in the Indo-European context, with the weak form of the adjective seen as the first tool of definiteness marking.

Diese 'schwachen' n-Bildungen haben ursprünglich individualisierenden Charakter, wie etwa griech. $\sigma \tau \rho \alpha \dot{\beta} \omega \nu$, ,Schieler (eigentl. ,der schielende') neben $\sigma \tau$ ¡áßós,schielend'; sie werden daher-im Gegensatz zum starken Adj.- - mit dem bestimmten Artikel verbunden, wie noch heute der gute Mann im Gegensatz zu (ein) guter Mann usw. (Krahe 1948:81) 
'These 'weak' n-formations have originally an individualizing character, as in Greek $\sigma \tau \rho \alpha \dot{\beta} \omega \nu$, 'squinter' (actually 'the squinting') next to $\sigma \tau p \alpha \dot{\beta} \beta{ }^{\prime} \varsigma$ 'cross-eyed'; they are therefore-in contrast to the strong adjectivesconnected to the definite article, as in today's contrast between der gute Mann 'the good-wK man' and (ein) guter Mann '(a) good-st man.'

The idea that the weak adjectival declension could have an individualizing function goes back at least to Osthoff (1876).

In modern North Germanic the weak form of the adjective is used if the NP is definite, and the strong when it is indefinite. In the period studied it was possible to use the strong form in in definite contexts, as illustrated below.

(77) hans siuk-t ben

his sick-st leg

(78) hans siuk-a ben

his sick-wK leg

'his sick leg' (Delsing 1994)

Such productive use of the strong form of the adjective ascribes new characteristics to familiar referents, while the use of the weak form is understood to denote a known characteristic of the familiar referent (Skrzypek 2012:6o-61). Although no longer grammatically correct in the Continental languages, ${ }^{9}$ this use is still found in Modern Icelandic (Naert 1969, Sigurðsson 2006, Thráinsson 2007), where the following NP patterns are possible.

(79) góð-ur maður

good-sT man

(80) góð-i maður

good-wK man

(81) góð-i maður-inn

good-WK man-DEF

9 With the exception of the adjective egen 'own', which appears in the strong form after possessives, e.g. mitt ege-t/* egn-a hus 'my own-STR/*own-wK house', but in weak form in defNPs, e.g. det egn-a hus-et 'the own-WK house-DEF' (see Lohrmann 2010 for further discussion). 
(82) góð-ur maður-inn

good-sT man-DEF

(based on Naert 1969)

The combination of the strong form of the adjective and the definite article implies an attributive reading of the adjective, while the weak form has a contrastive function.

(83) Ég horfði upp i blá-an himin-inn.

I looked up into blue-sT sky-DEF

'I looked at the sky that was blue.'

(84) Ég horfði á blá-a bíl-inn.

I looked at blue-WK car-DEF

'I looked at the blue car [and not the red].' (after Thráinsson 2007:3)

Skrzypek (2012) quotes a similar use from Yngre Västgötalagen, a Swedish legal text from ca. 128 o.

(85) Konce firigicer manni feellir hana luct

woman kills man charge her closed.NOM.F.ST

hœrсаппетрд-in.

jury-DEF

'If a woman kills a man, she shall be charged by a closed jury.' (YVL FB:12; Skrzypek 2012:6o)

In this example the intended meaning seems to be descriptive, i.e., 'a jury that is closed' and not contrastive 'the jury that is a closed one, out of a number of juries, some open'. Such variation in historical texts is studied in Delsing (1994), mainly in connection with possessives, as in (77-78). Naert (1969) is a study of Modern Icelandic.

While the formation of the weak adjectival paradigm belongs to the ProtoGermanic period, the grammaticalization of the postposed, cliticized definite article takes place in the common history of North Germanic (see Table 10 for an overview of proposed dates). As previously stated, the rise of the postposed, suffixed definite article has attracted by far the most attention. The older research, originating with Grimm (1898), focuses mainly on the unusual form of the article as compared to the West Germanic and Romance languages (apart from Romanian), and the main aim of these publications was to account for the processes that led to the definite article taking this particular form. More recent 
research, in particular Dahl (2004), Skafte Jensen (2006) and Skrzypek (2012), focuses more on the functional evolution of the original distal demonstrative, which is the source of the definite article in North Germanic.

Being an instance of grammaticalization, the rise of the definite article consists of two major ingredients: the formal development, in the course of which the original free lexeme loses its independence and is gradually cliticized to the preceding noun in its inflected form, and the functional development, which consists of a number of stages, in which the form begins to be used in new contexts. The two developments are not entirely simultaneous. Based on the textual evidence we may claim that the formal cliticization had begun before the oldest extant texts were written (excluding the Runic inscriptions, the majority of which are lapidary, although those that are longer and can be dated, such as the Rök inscription from ca. 8oo, exhibit no signs of either the definite article or the cliticization of the demonstrative). In the oldest Icelandic texts, we find examples of clitics, as we do in the oldest Danish and Swedish texts (which are about a century younger). However, the distribution of the form is not regular and is difficult to map. The functional development can be studied to a large extent in the available textual material. Thus, the grammaticalization of the definite article straddles the pre-textual and textual epochs in the history of the North Germanic languages.

Etymologically, the definite article originates in a distal demonstrative pronoun, which in the western sources (Icelandic and Norwegian) may appear as either inn (or enn) or hinn, and in the eastern ones (Danish and Swedish) as hin only.

When cliticized (to an inflected form of the noun) it invariably appears as -in and retains its own inflection for case, number and gender, which we illustrate in Table 9 with Swedish examples.

The formal development from a free lexeme to an enclitic and later to a suffix (for a debate on the status of -IN in modern North Germanic languages see Faarlund 2007, Stark et al. 2007, Börjars and Harries 2008) required the postposition of the demonstrative pronoun with respect to the noun. Two hypotheses have been put forward concerning the exact circumstances. The first, proposed by Grimm in 1898 and later developed by Delbrück in 1916, assumes that the demonstrative was part of the adjective phrase, and that its original role was to mark the adjective, not the noun, as definite. The other hypothesis, found in Nygaard (1905) and later developed by Pollack (1912), assumes the postposition of the demonstrative itself, without the adjective, possibly to mark a different reading from that of the preposed demonstrative (see also Polish examples of anaphora, 147-148 in section 5.3.1). Both hypotheses are illustrated in (86). 
TABLE 8 The inflectional paradigm of $(h)$ inn

\begin{tabular}{lllll}
\hline & & M & F & N \\
\hline SG & & & & \\
& NOM & hinn & hin & hit \\
GEN & hins & hinnar & hins \\
DAT & hinum & hinni & hinu \\
ACC & hinn & hina & hit \\
PL & NOM & hinir & hinar & hin \\
& GEN & hinna & hinna & hinna \\
DAT & hinum & hinum & hinum \\
ACC & hina & hinar & hin
\end{tabular}

TABLE 9 Definite nouns in Old Swedish (adapted from Skrzypek 2012:67)

\begin{tabular}{|c|c|c|c|c|}
\hline & & $\begin{array}{l}\text { M } \\
\text { 'day' }\end{array}$ & $\begin{array}{l}\text { F } \\
\text { 'journey' }\end{array}$ & $\begin{array}{l}\text { N } \\
\text { 'ship' }\end{array}$ \\
\hline \multirow[t]{4}{*}{ SG } & NOM & daghr-in & færp-in & skip-it \\
\hline & GEN & daghs-ins & færp-inna(r) & skips-ins \\
\hline & DAT & daghi-num & færp-inne & skipi-nu \\
\hline & ACC & dagh-in & færp-ena & skip-it \\
\hline \multirow[t]{4}{*}{ PL } & NOM & dagha-ni(r) & færbe-na(r) & skip-in \\
\hline & GEN & dagha-nna & færpa-nna & skipa-nna \\
\hline & DAT & daghum-in & færpom-in & skipum-in \\
\hline & ACC & dagha-na & færpe-na(r) & skip-in \\
\hline
\end{tabular}

$\begin{array}{llll}(86) \text { a. } \mathrm{N}(h) \text { inn Adj } & \rightarrow & \mathrm{N} \text {-inn Adj } & \text { (Grimm 1898, Delbrück 1916) } \\ \text { b. } \mathrm{N}(h) \text { inn } & \rightarrow & \mathrm{N}-\text {-inn } & \text { (Nygaard 1905, Pollack 1912) }\end{array}$

The two reconstructions paint a different picture: the second assumes postposition of the demonstrative, most likely motivated stylistically or serving to place more emphasis on the discourse referent, while the first assumes a connection between the demonstrative and the adjective, and the postposition as a by-product of the natural and grammatically correct postposition of the adjectival phrase.

Neither of the hypotheses is particularly well-documented, largely because the process predates the oldest extant sources. There is evidence of tendencies 
to postpose and cliticize grammatical material, visible, for instance, in the form of the morphological s-passive. Delbrück's model example, maðr inn gamli 'man that old-wK', finds support in a textual study by Musinowicz (1911), which is a cornerstone of the hypothesis. Critics, Pollack (1912) and Møller (1945) in particular, observe that the textual evidence consists largely of postposed epithets with proper names (e.g., piauriks hin purmupi 'Pjóðríkr-Theodoric the great, the valiant' in the Rök inscription, although new interpretations suggest that it may be an appellative after all, i.e., rikr hin purmupi 'man-NOM the valiant'; see Ralph 2007 and Holmberg 2015). This in itself does not exclude the possibility of cliticization, as demonstrated by the spelling of a name with epithet as Erik-i-n-um hoelghee 'Erik-DAT-DE F-DAT holy-WK' (Kock 1919:98-99, also quoted in Börjars and Harries 2008:297). On the other hand, data supporting the Nygaard-Pollack reconstruction are equally scarce, with one often-quoted example from the Strøm runic inscription, dated at ca. 600.

\section{(87) wate hali hino horna}

wet stone DET horn

'Let the horn wet this stone!' (N KJ5o)

Although the postposition of the demonstrative is by no means rare, there are few examples with the demonstrative hinn, the majority involving other demonstratives, sá 'this' or sjá 'this here', as in (88).

(88) stein saR

stone DEM

'stone this' (U 10)11

(89) poriR ok hroða let-u reisa stein pennsa

poriR and Hroða let-PL raise stone DEM

'Thore and Hroda had this stone raised.' (U 429)

Although most researchers are in agreement as to the etymology of the definite article (one exception being Gjerdman 1924; see also Perridon 1989) —albeit with some differences with respect to the actual context (postposed demonstrative or postposed adjectival phrase) - the proposed timeframes of the cliticization of the postposed demonstrative are widely divergent. In Table 10 we present a concise overview of the proposed dates.

The earliest instances of the postposed, cliticized article come from Runic inscriptions from the 11th century, i.e., mirk-it mikla 'landmark-DEF great' (Sö 41) and ant-ini 'spirit-DEF' (U 669). 
TABLE 10 Proposed dating of the cliticization of hinn in North Germanic (adapted from Skrzypek 2012:74)

Proposed dating

Author

\begin{tabular}{ll} 
Ancient Norse/Old Norse & Delbrück (1916), Neckel (1924) \\
\hline 5 Oo-1100 & Syrett (2002) \\
Old Norse & Gjerdman (1924), Larm (1936), \\
& Barnes (2008) (cf. Börjars and Harries \\
& 20o8:295f. $)$ \\
The Viking Age & Boor (and von Friesen) (1928) \\
(just before the legal texts were written) & Seip (1958) \\
10oo-1150 & Braunmüller (1982) \\
With the first written texts & Hansen (1927) \\
Ca. 1200 & Delsing (2002) \\
\hline
\end{tabular}

As we have mentioned before, of the three processes leading to the formation of the defNP in North Germanic, it is the rise of the suffixed article that has been very much the focus of research, from Grimm (1898), Hodler (1954) to Stroh-Wollin (2016), with the older studies focusing on reconstructing the process of cliticization and the recent ones on its functional development.

The rise of the preposed definite article, on the other hand, which seems to be the most recent development, has mainly been considered in terms of the structure of the defNP, in particular in terms of what is called double definiteness: the co-occurrence of both pre- and postposed definite articles within one defNP; see the next section for a short discussion of this development (see also Hirvonen 1987, 1997). In recent years there have been a number of publications concerning the preposed article as an adjectival article, in particular Pfaff (2019), bringing this development into focus.

With respect to the Old Icelandic data, it has been proposed that the occasional variation between the preposed demonstrative sá and the cliticized-inn was free, that is, either form could be used to achieve the same effect (Nygaard 1905:31, Delbrück 1916; see also Møller 1945).

Oft hat man den Eindruck, als könnte statt inn auch sá stehen und umgekehrt: Ld. 125.9 könnte statt pingit wohl auch pingit pat gebraucht sein, 124.10 statt pinginu auch peim pingi, und andererseits Eb. 85.5 statt til peirar ferðar auch tilferðarinnar. (Delbrück 1916:72) 
'Often one has the impression that inn could be used instead of sá and vice versa: Ld. 125.9 could have used instead of pingit likewise pingit pat, 124.10 instead of pinginu even peim pingi, and in other places Eb. 85.5 instead of til peirar ferðar even til ferðarinnar.'

This belief is grounded in the fact that for those researchers the category of definiteness and its expressions in Old and Modern Icelandic constituted two completely different systems (see also Skafte Jensen 2007b for a theoretically motivated account similarly demarcating the Old and Modern Danish systems with respect to the function of the NP).

We have so far described the rise of the definite article as if it were common to the whole of Scandinavia. There is one area, however, where the preposed definite article is the only one that has grammaticalized, and the postposed definite is not to be found. It has long been noted that the Danish dialects of western Jutland have the preposed definite article only, similarly to the West Germanic languages, but in contrast to the North Germanic ones (Møller 1974).

\section{Standard Danish}

(9o) hus-et

house-DEF

'the house'

West Jutland

(91) \& hus

DEF house

'the house'

This peculiarity was attributed in older research to Low German influence, a notion that has been (quite convincingly) refuted in Møller $(1945,1974)$ and Perridon (1996, 2009). Perridon argues that the grammaticalization of definiteness in North Germanic began long before language contact with Middle Low German started to play a significant role in Scandinavia. The distinct pattern of the Jutlandic dialects is probably due to word order differences, i.e., preposition vs. postposition of attributes and demonstratives. It seems that the original postposition was the default order in Scandinavia long enough for the definite article to grammaticalize as a suffix, with the exception of Jutland where the order underwent a major change, resulting in the preposition of the attributes and determiners, before the grammaticalization process began. Møller (1945) gives an alternative account, also with respect to the etymology of the preposed article. 


\begin{tabular}{|c|c|c|c|c|}
\hline & & $\mathbf{M}$ & $\mathbf{F}$ & $\mathbf{N}$ \\
\hline \multirow[t]{4}{*}{ SG } & NOM & sá* & sú $^{*}$ & pat \\
\hline & GEN & pess & peir(r)ar & pess \\
\hline & DAT & peim & $\operatorname{peir}(r) \mathbf{i}$ & bví \\
\hline & $\mathrm{ACC}$ & pann & pá & pat \\
\hline \multirow[t]{4}{*}{ PL } & NOM & peir & pær & pau \\
\hline & GEN & peir $(r) a$ & $\operatorname{peir}(\mathrm{r}) \mathrm{a}$ & peir(r)a \\
\hline & DAT & peim & peim & peim \\
\hline & $\mathrm{ACC}$ & pá & pær & pau \\
\hline
\end{tabular}

* later replaced by the ACC forms $p \ltimes n, p a$

It has been widely accepted that the source of $\propto$ is the demonstrative pæen (the continuation of the nominative sá) (Hansen 1927).

This reconstruction implicitly makes the development of sá parallel with the grammaticalization of the same demonstrative as the preposed definite article, e.g., den gamle man and den gamle mannen 'the old man' in Standard Danish and Swedish respectively. In this reconstruction there would have been no cliticization of hinn, or it would have been so limited as not to become successfully established. Hansen (1927) quotes a number of examples with the cliticized hinn, all in the genitive case, from legal prose, e.g., by-s-in-s logh village-GENDEF-GEN law, 'the law of the village'. Møller (1945) refutes these examples, and is instead of the opinion that the origins of the preposed definite article in western Jutlandic dialects lie in the same demonstrative that gave rise to the cliticized definite in other parts of the country (and elsewhere in Scandinavian), i.e., hinn, or more accurately, one of its competitive forms, inn (Møller 1945:7781 ). Even if the textual documentation is not conclusive for either reconstruction, Møller raises an important objection to the etymology of $\propto$ in $p \propto e n$, namely the improbability of the phonological reduction of the initial $p \cdot{ }^{10}$ If the source of the preposed definite is instead the demonstrative inn, its present form is quite easily understood. In this reconstruction he is not alone; similar ideas are presented in Boor (1928), Schütte (1922), and very explicitly in Thorsen (1901). For more recent accounts see also Perridon (1996) and Stroh-Wollin (2018).

10 As one reviewer points out this is not entirely impossible. Subordinator $a t(t) / a$ ' 'that' is most likely descendant of *pat. 
2.4.1.1 The Development of Double Definiteness in North Germanic

As mentioned in section 1.2, modern Swedish, Norwegian and Faroese exhibit double definiteness in NPs modified by adjectives or other prenominal modifiers. If the head noun is preceded by a modifier, the latter must be preceded by a preposed definite article, while the head noun itself is marked by a suffixed definite article, as in (92). In Danish the two definite articles are in complementary distribution, and only the preposed article is present in NPs modified by adjectives, as in (93); see also Table 1 in section 1.2. For a detailed analysis of differences between double definiteness in Swedish and Norwegian and the non-double structure in Danish from the generative point of view see Julien (2005). Icelandic exhibits a different pattern altogether, namely just the suffixed article appears on the head noun and usually no preposed article is used (see also examples in 1 in section 1.2.1.1).

\section{Swedish/Norwegian}

(92) den gaml-e mann-en

DEF old-WK man-DEF

'the old man'

\section{Danish}

(93) den gaml-e mand

DEF old-WK man

'the old man'

As demonstrated above, the origin of the suffixed definite article in North Germanic languages is to be sought in the distal demonstrative hinn (see Tables 8 and 9). The preposed definite article, on the other hand, has its origins in the demonstrative sá 'that' (see Table 11 above). While the suffixed definite article was cliticized to the head noun around the year 1000 (Stroh-Wollin 2015:102; see also Table 10 on various proposed dating), the preposed definite article is a later development that began establishing itself around the year 1400 (Stroh-Wollin 2015:134). The development of double definiteness has been discussed most notably by Larm (1936), Lundeby (1965), Hirvonen (1997), and more recently by Faarlund (2009), Stroh-Wollin (2015) and Pfaff (2019). Interestingly, the Swedish and the Norwegian way to double definiteness exhibit different patterns.

Firstly, as regards the Old West Nordic variety, as Faarlund (2009) and StrohWollin (2015) demonstrate, the two demonstratives (hinn and sá) could cooccur in Old Icelandic and Old Norwegian, as in the following examples. 
Old Icelandic (Heimskringla, ca. 1300)

(94) pau in stóru skip those DEF large.wK ship.PL

'(those) the large ships' (Faarlund 2009:13)

Old Norwegian (Sankt Olavs järtecken i Norska homilieboken, ca. 1200)

(95) sá hinn helgi maðr

that DEF holy.wK man

'(that) the holy man' (Stroh-Wollin 2015:117)

The possibility for the demonstrative and the definite article (hinn) to co-occur is attributed to the differences in their referential properties and semantic functions: while the incipient definite article renders the DP definite and specific, the demonstrative provides deictic properties and uniqueness interpretation of the DP (Faarlund 2009:14; Stroh-Wollin 2015:117). Preposed hinn is also tightly bound to the adjective. See example (96) where hinn appears before every adjective, while sá appears only once per phrase, hinn is thus often analysed as an adjectival article (Stroh-Wollin 2015; see especially Pfaff 2019 for a detailed account of the development of adjectival article in Icelandic).

Old Icelandic (Brennu Njáls saga, ca. 1350)

(96) skaða pann hinn mikla og hinn illa damage that (sá) DEF extensive and DEF bad 'that extensive and bad damage' (Pfaff 2019:27)

Further, as the demonstrative sá grammaticalizes into a definite article in Old Norwegian, the adjectival hinn becomes redundant, as the model in Table 12 illustrates with an example of the NP 'the holy man'. Since the structure with the preposed article but no suffixed article (of type den gamle man 'DEF old.wK man') was frequent in Old Norwegian (Lundeby 1965, Stroh-Wollin 2015), it is assumed that this structure in combination with the definite-marked noun (mann-en 'man-DEF') gave rise to double definiteness in Norwegian.

As regards Old Swedish, the preposed hinn is very early replaced by poenn (originally sá), and hinn does not occur in Old Swedish texts with the same frequency as it does in Old Norwegian and Old Icelandic. Stroh-Wollin (2015:133) demonstrates that in Old Swedish texts poenn could have two functions: either as an element equivalent to Norwegian and Icelandic pre-adjectival hinn (referred to as $p \propto e n n_{1}$ by Stroh-Wollin), or as a definite article equivalent to the Old Norwegian sá $\left(\right.$ pøenn $\left._{2}\right)$. Since pœenn in Old Swedish is very early on combined with the definite-marked form of the noun, it is assumed to be an adjecti- 
TABLE 12 Double definiteness development in

Norwegian after Stroh-Wollin (2015:132)

\begin{tabular}{lll} 
Determiner & Adjective & Head noun \\
& hinn helgi & maðr \\
sá & $\begin{array}{l}\text { hinn helgi } \\
\text { helgi }\end{array}$ & $\begin{array}{l}\text { maðr } \\
\text { má }\end{array}$ \\
\hline den & heilage & mannen \\
\hline
\end{tabular}

TABLE 13 Double definiteness development in

Swedish after Stroh-Wollin (2015:133)

Determiner Adjective Head noun

\begin{tabular}{|c|c|c|}
\hline peenn $_{2}$ & $\begin{array}{l}\text { pœnn }_{1} \text { gamli } \\
(\text { pœnn } \\
1) \text { gamli } \\
\text { gamli }\end{array}$ & $\begin{array}{l}\text { mannin } \\
\text { mannin } \\
\text { mannin }\end{array}$ \\
\hline den & gamle & manner \\
\hline
\end{tabular}

val article (like hinn) rather than fully developed definite article. Because of this the adjectival ponn $n_{1}$ becomes optional at a later stage, until poenn $n_{2}$ becomes grammaticalized as a determiner and a fully productive preposed definite article (either through reanalysis of adjectival poenn or through broader usage of the demonstrative poenn); see the model in Table 13 with an example of the NP 'the old man'.

Thus, in Norwegian double definiteness was reached through a construction with just the preposed article and no suffixed article, namely den gamle man $>$ den gamle mannen. In Swedish, on the other hand, double definiteness was reached through the structure with the suffixed definite article, namely gamle mannen > den gamle mannen. For a detailed diachronic study and a discussion of earlier approaches to this development see Stroh-Wollin (2015). 


\subsubsection{Definite Article in Old Norse and Icelandic:Johnsen (1975), Faarlund (2009), van Gelderen (2007)}

Although the majority of studies of the rise of the definite article take into consideration the Old Norse data, there are a number of larger studies dedicated solely to the Old Norse and Icelandic material (Sprenger 1977), and a number of studies which focus on the eastern branch. The study by Johnsen (1975) is unusual in that she combines four types of source material: the mythological and heroic Eddaic lays, the sagas, and Runic inscriptions. The last of these is not often found in Old Norse studies; strictly speaking the inscriptions represent both eastern and western vernaculars, as the author did not restrict the corpus to Norwegian Runic inscriptions, which might have ensured more continuity with the Icelandic texts.

The review of Icelandic sources begins with Hárbarðsljóð 'Lay of Hárbarðr', an Eddic poem which is considered to be written in a colloquial style, most likely to represent the spoken variant of contemporary Icelandic (Johnsen 1975:60). From this passage Johnsen excerpted 26 definite forms with suffixed -inn, of which the majority are concrete, inanimate nouns that are prepositional objects (Johnsen 1975:61). Interestingly, Johnsen also analyses independent uses of hinn (her terminology), i.e., those without any noun, as in (97).

(97) Hins vil ec nú spyria, hvat pú heitir.

This want I now ask, what you are.called

'Now I want to ask this: what is your name.' (Johnsen 1975:62)

This use is hardly consistent with distal deixis ('that'), but rather signifies proximal deixis ('this'). This observation is of importance when considering the likely source of the definite article, which would be the distal rather than the proximal demonstrative. As regards the free form inn, which is also found in the text, it occurs only with adjectives, either as part of full NPs (98) or as nominalizations (99).

(98) Ec drap Piaz-a, inn prúðmóðg-a iqtun.

I killed Piazi-ACC DEF heroic-WK giant.ACC

'I killed Diazi, the heroic giant.'

(99) ina línhvít-o

DEF linen.white-wK

'the (one) white as linen' (Johnsen 1975:66) 
Furthermore, Johnsen observes that in the Prymskviða 'Prym's poem' from Poetic Edda there appear to be no uses of the definite suffix and no postposed instances of hinn or inn. Instead, the examples found there are always preadjectival and used when the adjective modifier is separated from the noun it modifies, as in (100), while when it is adherent to the noun, the demonstrative inn is not used, as in (101).
(100) in arm-a iqtn-a systir
DEF poor-WK giant-PL.GEN sister
'the poor sister of giants'
(101) hring-a rauð-a
ring-PL.ACC red-wK
'red rings' (Johnsen 1975:69)

The separation between the adjective and the noun may come in the form of an intervening element, but it can also be deduced from the metric conditionsthe phrases are separated into parts by the caesurae which separate a long line into the traditional two half-lines of the fornyrðislag-metre. This function of inn is reminiscent of the linking article as proposed in Himmelmann (1997).

The conclusions presented in Johnsen's study are that the incipient definite article plays a role in emphasis, which is illustrated among other things by its higher frequency in depictions of dramatic incidents and with the historical present tense.

The evidence reveals a form which, while relatively empty of content, began to be used for narrative stylistic purposes with substantives, and which persisted over a long period of time, in spite of first partially and then, beyond the scope of this paper, totally losing its independence of form and its strength of function. (Johnsen 1975:132-133)

Interestingly enough, Johnsen is also one of the few scholars who draw attention to the developments of einn 'one'. She mentions specifically the potential confusion that may arise from the formal similarities between inn (or its weakened variant enn) and the numeral einn, but also from a certain functional overlap between the two, namely the fact that both could appear in postposition with respect to a noun to make it more real or draw attention to it, and- - a fact rarely noted — both inn and einn occur predominantly in the singular (Johnsen 1975:131). 
Faarlund (2009) is concerned with the changes which the postposed article underwent in Norwegian, based on textual material gathered from Old Norse, as it was written (and presumably spoken) in Norway and Iceland in the 12th and 13th centuries, and from the nynorsk variety of Modern Norwegian. The focus of the text is the status of the definite article-which as Faarlund argues, is a clitic in Old Norse and an affix in Modern Norwegian - the process in which this change has taken place and its consequences for the Norwegian NP. The arguments in favour of the proposed classification include existence of free counterparts of clitics (hinn is no longer found in nynorsk), the ability of affixes to affect the host (argued on the basis of the plural definites in nynorsk), existence of arbitrary gaps (the definite article in nynorsk does not attach to nouns with final -en) and lack of inflection of affixes (Faarlund argues that the definite in nynorsk constitutes the noun's inflection, while in Old Norse it receives an inflectional ending of its own).

Much of the argumentation is founded on the observation that in Old Norse it is possible to combine demonstratives and incipient definite article, e.g., pau in stóru skip 'those the large ships' (Faarlund 2009:13), which is impossible in nynorsk, e.g., *dei dai store skipa 'those the large ships' (Faarlund 2009:18). The major focus of the text is the formal difference in status between clitic -in and affix -in and the functional aspects of the change are not pursued.

In her 2007 study of cyclicity of article development, Elly van Gelderen considers in detail three Germanic languages (groups of languages), including Old Norse and the consecutive developments in its daughter languages. The focus of the study is the development of a demonstrative into a definite article accompanied by loss of the proximal/distal distinction and a consecutive renewal of the demonstrative by e.g., locative markers (see e.g., Modern Swedish den här 'this here' and den där 'this there' which are examples of the same process), illustrating the cyclical nature of language change.

As has been long recognized, demonstratives are far more frequent in the world's languages than definite articles are. Van Gelderen stresses that while the former express definiteness and locality with respect to the speech event, the latter only express definiteness (van Gelderen 2007:304), however, the border between the two forms is often fuzzy and their classification difficult (van Gelderen 2007:276). In her account, the source of the definite article is a locative adverb hinn/hitt 'here' (sic, van Gelderen 2007:294), which becomes reanalysed as a head and becomes a clitic nominal marker in Old Norse, from which the modern definite article stems. Then the Old Norse locative marker is renewed through a demonstrative, such as sá 'that', which being a deictic element becomes incorporated as a specifier of the DP. These demonstratives correspond to det and den in modern Mainland Scandinavian. 


\subsubsection{Definite Article in Danish: Skafte Jensen (2007a)}

Skafte Jensen (2007a) considers both definite and indefinite articles as well as the scope of the use of BNs in Old and Modern Danish. Of particular interest are comparisons between texts of similar age representing different genres, in which striking differences in the use of defNPs and BNs can be found. She quotes two examples, from a legal text (Skånske Lov from ca. 1350) and a religious narrative (Sjcelens Trøst from ca. 1425).

SL, ca. $135^{\circ}$

(102) a. Barn um foth wartheet tha scal thcet hafwee gud father oc child if born be then shall it have god father and gud mother a kyrkiu oc fa sin cristindom af preste. god mother in church and get its baptism of priest

Translation to Modern Danish

b. Hvis et barn bliver født, da skal det have en if INDF child becomes born then shall it have INDF gudfader og en gudmoder $i$ kirke-n og døb af godfather and INDF godmother in church-DEF and baptism of en prcest/prcest-en.

INDF priest/priest-DEF

'If a child is born it shall have a godfather and a godmother in church and be baptized by a priest/the priest.' (after Skafte Jensen 2007a:30o, translations to Modern Danish by Skafte Jensen)

ST, ca. 1425

(103) a. folk-it spordhe hwat som honum var. Han swarathe people-DEF asked what which him was he answered her heengr ofvir mek en stor steen oc vil vpa mek falla. here hangs over me EN large stone and will upon me fall The callatho thit prost-in at han skulde sek granliga they called there priest-DEF that he should self properly skrifta. Han skriftathe sek som han boest cvnne. tha confess he confessed self as he best could then vligaval blef sten-in hongande.

nevertheless remained stone-DEF hanging

Translation to Modern Danish

b. folk-et spurgte ham hvad der var med ham. Han people-DEF asked him what there was with him he 
svarede her hanger en stor sten over mig som vil answered here hangs EN large stone over me which will falde ned på mig'. De hidkaldte prost-en for at han fall down on me they summoned priest-DEF for that he kunne skrifte. Han skriftede så godt han kunne, men could confess he confessed as well he could but alligevel blev sten-en hæengende. nevertheless remained stone-DEF hanging 'The people asked what was the matter with him. He answered: 'here hangs a large stone over me which will fall down on me'. They summoned the priest so that he could confess his sin. He confessed as well as he could but still the stone remained hanging.' (after Skafte Jensen 2007a:30o, translations to Modern Danish by Skafte Jensen)

As illustrated by the examples, the more recent, religious text displays an article system identical to the modern Danish one and quite different from the Old Danish one as illustrated by examples (102a and b). Without unreservedly stating that a significant linguistic change has taken place within a relatively short period of time (an issue addressed also in Delsing 2014), Skafte Jensen continues to compare the two systems with particular reference to the scope of the use of BNs, an issue seldom addressed in diachronic linguistics.

\subsubsection{Definite Article in Swedish: Larm (1936), Skrzypek (2012), Dahl (2004 and 2015), Stroh-Wollin (2016)}

Larm (1936) is the first monographic study of definiteness in Swedish, following his 1933 article. It is based on a corpus of texts representing all genres. Even though it is atheoretical from the modern perspective, it includes ideas which could be incorporated in studies of grammaticalization, mainly that the rise of the definite article involves the spread of the form to new functions. Larm identifies what we would call textual uses as the first step in the development of the definite article.

Skrzypek (2012) is a study of both definite and indefinite articles in Old Swedish (1225-1526). Based on the grammaticalization models of Greenberg (1978) and Heine (1997), the study focuses on the functional development and the use of the original demonstrative in new contexts. The author differentiates between textual and non-textual uses, placing the anaphoric (direct and indirect) ones into the first category, and the larger situation uses and generics in the latter. The development clearly proceeds from the textual to non-textual uses, and indirect anaphora is singled out as the switch context (Heine 2002) in the development. The analysis of examples is completed by simple frequency 
analysis, which reveals a significant rise in the frequency of the definite suffix between $135^{\circ}$ and $145^{\circ}$, with lower values in the final part of the studied period, i.e., $145^{0}-15^{26}$. The reason for this peak is, according to Skrzypek, the tendency to mark abstract nouns as definite, especially those referring to the Christian virtues and vices (examples 104-105). She terms such uses co-textual, arguing that their definiteness arises from the type of text in which they appear.

It is interesting to note that they are not wholly disconnected from the texts, although they are not introduced (linguistically) by any other prior referents; they may be considered 'introduced' by the text genre-a collection of moralizing stories to be read in a convent or at a religious gathering or by a pious Christian on his or her own, but always in clear connection to religion. The definiteness of concepts such as dygden 'the virtue' or sanningen 'the truth' arises not out of the textual situation but a co-textual one- the context in which the text is produced and read. There are frequent references made to different virtues, like ödmiukt 'humility' and vices, like högfürdhet 'vanity', which are likewise regularly marked with -IN and cannot be explained on the basis of linguistic information in the texts. Neither is it easy to think of them as uniques or generics. (Skrzypek 2012:148)

(104) Thu giuir var herra hugnadh-in til at lätta os $\mathrm{mz}$ hop-ino you give our lord mind-DEF to to relieve us with hope-DEF at vi skulum ey vanskas oc dröuils-in til ödhmiukt-in-na that we shall not run.short and grief-DEF to humility-DEF-GEN gömilse

preservation

'You give your mind to the lord, to relieve us with hope so that we shall not falter and grief for the preservation of humility.' (Bo 11, ca. 139o)

(105) ok thikkir mik thän vara komin til höxsta oc vansammasto and thinks me then be come to highest and most.beautiful fulcomlikhet-zs-in-s trappo perfection-GEN-DEF-GEN ladder 'And I think I am come to the highest and most beautiful ladder of perfection.' (Bo 31, ca. 139o; both examples after Skrzypek 2012:148-149)

Concrete nouns can also be found in this category possibly understood as instances of larger situation use, referring to objects familiar to readers of the text, as in (106). 
(106) Nw tha the komo fore stallit som är thz skiulit som var now that they came for stable which is this shed which our herra var föddir ij

lord was born in

'They now came to the stable, which is the shed that our Lord was born in.' (Bo 1, ca. 1390; Skrzypek 2012:145)

Östen Dahl's (2004) study is a contemporary review of the use of both pre- and postposed definite articles in non-standard varieties of Swedish, with some references to other North Germanic vernaculars. Despite the fact that it is not diachronic, it is highly relevant to the present study.

The point of departure is an observation of how widely varied the defNP is in modern North Germanic, where the two articles are in complementary distribution in certain contexts, and may sometimes appear in the same defNP (see also Chapter 1). The possibilities are even more varied when one considers, as Dahl does, the non-standard varieties, which in contrast to the standard ones - with their more or less clean-cut borders-form a dialect continuum. This variation, according to Dahl, is the result of two competing grammaticalizations, the older one, originating in the north, of the postposed suffixed article, and the more recent one, originating in the south, of the preposed definite article. The only area where the latter has undergone full grammaticalization is the south of Denmark (see Møller 1945); in other parts its development was frozen, at different stages, since it presumably had to compete against the older and better established postposed definite article. In the areas where grammaticalizations 'met', a compromise of sorts was reached, with both forms uniting within the same NP. In the north the postposed definite prevails, and its use is spread wider than in the south.

The two main definite article types in Scandinavia — called here "P-articles" and "S-articles" - thus represent two separate grammaticalization processes represented in overlapping geographical areas with different "centres of gravity". The S-article (historically oldest in the area) has reached its fullest development in north-eastern Scandinavia. The P-article (a newcomer from the south) has been frozen at a relatively early stage and has left some areas virtually untouched. (Dahl 2004:178)

Examples quoted in the study illustrate among other things the advanced stage of grammaticalization of the suffixed article (Dahl's S-article) in the northern dialects, exceeding the use of the article in the standard variety of modern Swedish. They include low referentiality uses (107), which in Standard Swedish 
would most likely be expressed by BNs, and non-delimited NPs (108), which would most likely be modified by lite 'some'.

Low referentiality uses of the definite article:

Nederkalix (Norrbotten)

(107) Jä skå tåla åom för dä, måmme, åt jä ållti I shall speak.INF about for you.DAT mother that I always veillt hå $i$ kjaatt män hä gja jo ät want-SUP have INDF cat but it go-PRS as.you.know not håa kjatta når man båo ini $i$ höreshöus. have-INF cat-DEF when one live-PRS in INDF rent-house 'I want to tell you, Mother, that I have always wanted to have a cat-but it isn't possible to have a cat (lit. the cat) when you live in an apartment house.' (Cat Corpus; Dahl 2004:174)

Non-delimited NPs with definite articles:

Våmhus (Dalarna)

(108) Ja, bara $i$ a faið in wi-ðn, so ska $i$ werm yes only I have-PRS get-SUP in firewood-DEF so shall I warm-INF miö-tsī a na.

milk-DEF for PRO.3SG.F.DAT

'[Granny says:] As soon as I have put in the firewood, I'll warm some milk for it (the cat).' (Cat Corpus; Dahl 2004:172)

There are also instances of the definite article used in presentation constructions with the dummy subject, which in Standard Swedish would be indefinite.

Presentation constructions with the dummy subject:

Skellefteå (Västerbotten)

(109) Hä gick skaplit att klaar sä, meda ’ä fanns it go-PST okay to survive REFL as.long.as it exist-PST rått-än å mus-än ... rat-DEF.PL and mouse-DEF.PL '[The cat thinks:] It was kind of $\mathrm{OK}$ [to live in the forest], as long as there were rats and mice ...' (Cat Corpus; Dahl 2004:173) 
While Dahl $(2003,2004)$ reviews and analyses the non-canonical uses of the suffixed definite article and the competition between the two definite articles in contemporary Swedish dialects, Dahl (2015) not only further develops these studies, but also offers a diachronic insight into the source of the variation (in this the account is radically different from the other analyses of the variation in the structure of the defNP in North Germanic, e.g., La Cara 2011). In his discussion, he refers to two possible grammaticalization paths beyond the 'classical' final stage of grammaticalization of the definite article in its generic uses: Greenberg's model from 1978, in which the development results in general affixes whose informative value includes gender and number (the title of Greenberg's paper is in fact 'How does a language acquire gender markers?') but not definiteness, or the development into specific articles as witnessed in Austronesian languages (Dahl 2015:245). However, the dialectal data do not support either of these paths. Instead, the definite suffix in Northern Swedish dialects seems to have developed some extended uses which are commonly associated with BNs in standard varieties, i.e., non-delimited uses, uses with quantifiers and low-referentiality uses of singular count nouns (Dahl 2015:246). According to Dahl, these uses could have been mediated through the generic use of the definite suffix, which is more widespread in the Northern dialects than elsewhere (see also Skrzypek, Kurek-Przybilski and Piotrowska 2020 for an analysis of generic expressions in modern Danish, Norwegian and Swedish). Such mediation would come about in contexts in which it is possible to choose between a generic noun phrase and an indefinite one, for example in habitual contexts. This is illustrated in (110), where the definite form induces a habitual rather than a generic interpretation.

\section{Sollerön (Ovansiljan)}

(110) An drikk mjotji.

he drink.PRs milk.DEF

'He drinks milk.' (Dahl 2015:247)

The spread to new functions could also have been facilitated by the form of the article, i.e., the fusion of the stem and the affix (Dahl 2015:201).

Stroh-Wollin (2016) gives a minimalist account of the rise of the definite article. In her contribution she highlights two aspects of the development that have received little treatment in the literature as yet, namely the variation between hinn and enn, and the internal order of the NP. It has been noted before that the demonstrative from which the definite article develops is spelled in the sources as either hinn or enn. The former is the only spelling found in the eastern languages (Danish and Swedish); the variation is found 
in the western sources (Norwegian and Icelandic). The presence of the initial $h$ - has been taken to be a reinforcement of the deixis of the original enn (see especially Perridon 1989). The absence of $h$ in definite forms, e.g., fisk-in and not *fisk-hin 'fish-DEF', suggests that either it was lost in cliticization or the cliticized form was in fact enn and not hinn. In this vein, Skrzypek (2009) argues that it could in fact have been enn that gave rise to the definite article, while hinn is a later formation. Stroh-Wollin (2016) suggests that the definite suffix in the eastern and western varieties is derived from two variants of the demonstrative: enn in the west, hinn in the east.

(111) Mainland Scandinavian

dag-s hin-s $>$ dag-s' $(h)$ in-s $>$ dag-s-in-s $(>$ dag-en-s $)$

(112) Icelandic

dag-s en-s > dag-s'en-s > dag-s-in-s (Stroh-Wollin 2016:13)

Her account finds some support in the Runic data (which predate the oldest extant text written in the Latin alphabet by some centuries), although the evidence is hardly conclusive. Nevertheless, we believe a more problematized consideration of the etymology of the definite article to be of great value.

Secondly, Stroh-Wollin convincingly argues that the factors which had an influence on the rise of the definite article also included a change in the internal order of the NP.

My hypothesis was that "noun first", as in stein penna and faður sinn, was the unmarked word order and that fronting of a modifier was a means to emphasize it. [...] On the whole, the investigation supports the view that "noun first" is unmarked and fronting of a modifier is pragmatically motivated. (Stroh-Wollin 2016:14-15)

The purpose of this brief and selective overview of the current state of research into the grammaticalization of the definite article was to demonstrate that, despite the fact that the problem has received due attention in the literature, it continues to present puzzles, making it worthy of further research. More specifically, the diversity of NP forms and the differences in the scope of the use of the definite article in the modern vernaculars suggests that these differences, although rooted in a common past, have arisen in the histories of the individual languages. 


\subsection{Previous Studies on the Grammaticalization of the Indefinite Article in North Germanic}

The rise of the indefinite article is surprisingly understudied in comparison with that of the definite article, although a number of larger studies, in particular concerning Swedish, have been published recently.

\subsubsection{Indefinite Article in Icelandic: Leijström (1934)}

Even though there is no indefinite article in Modern Icelandic, there are articlelike uses of the numeral 'one' in Old Icelandic texts, which have attracted the attention of historical linguists. The most extensive study is that of Leijström (1934), who systematically compares the use of einn in two groups of sagas: the so-called family sagas, considered indigenous and free from foreign influence, and the so-called chivalric sagas, which were inspired by continental (mainly French) romances.

Leijström finds a number of instances in which einn is used as the indefinite article would be used, limited to three major types: presentation of a new discourse referent (individual), similes (as a king), and non-specific uses when there is some expectation of a potential referent (e.g., ger grof eina 'make a cavity'). None of the uses is obligatory. He further finds that the indefinite article in other North Germanic languages is a result of language contact with Middle Low German, and its absence in Icelandic can be explained by the isolation of the population (see also Heine and Kuteva 2005). We will return to Leijström's study and other smaller studies in section 5.6 , when we consider the developments in Icelandic beyond $155^{\circ}$.

\subsubsection{Indefinite Article in Danish: Skafte Jensen (2016)}

In her 2016 article, Skafte Jensen considers the textual evidence from the oldest Danish texts (apart from Runic inscriptions), namely legal prose. She quotes examples clearly illustrating the lack of the indefinite article and the scope of the use of BNs in Danish.

(113) Varthcer kunu døth. oc lifwcer barn aftcer. oc [...] um them becomes woman dead and lives child after and if them skil um. ath barn fic cristindom

divides about that child got Christianity 'If a woman dies and a child survives her, and [...] there is a disagreement as to whether the child was christened.' (SL, after Skafte Jensen 2016:264) 
Interestingly, the earliest instances of the article-like use of the numeral 'one' are similar to those identified in Icelandic, i.e., presentative uses (examples 114115) and similes (example 116), which can be found as early as ca. 1300, even though such uses are sporadic.

(114) warthcer swa at en man scecter anncen um sar becomes so that EN man sues another about wound(s) 'if it so happens that one man sues another about wound(s)' (ErL, ca. 1300)

(115) Swa com en rost af himen so came EN voice of heaven 'Then came a voice from Heaven' (SC, 14th century)

(116) E uar han sum eet lamb always was he like EN lamb 'Always he was like a lamb' (Lam, 14th century; Skafte Jensen 2016:269)

Examples like (114) may, according to Skafte Jensen, have constituted bridging contexts for the grammaticalization of the indefinite article. She further claims that by the $15^{\text {th }}$ century the use of the indefinite article is very much as it is in Modern Danish (in this genre).

\subsubsection{Indefinite Article in Swedish: Brandtler and Delsing (2010), Skrzypek (2012), Stendahl (2013)}

The grammaticalization of the indefinite article in Swedish is well studied in comparison with other North Germanic languages. Apart from the references to the development found in Leijström (1934) and Terner (1922), there are a number of recent studies devoted to the issue.

Brandtler and Delsing (2010) is the first treatment of the subject where the rise of the indefinite article is studied against Heine's grammaticalization model. The study is based on four religious texts written between 1330 and $145^{\circ}$ and the authors' conclusion is a confirmation of the model's predictions, with the grammaticalization of the indefinite article more or less completed by the middle of the $15^{\text {th }}$ century.

The development is studied in similar vein in Skrzypek (2012), where a larger and more mixed (in terms of genre) corpus exhibits the same timeline of the development and the gradual acquisition of new functions. It should also be noted that a more detailed inspection of the position and syntactic function of indefNPs reveals that at the onset of the grammaticalization, the presen- 
tative function is strongly associated with initially placed subjects. Skrzypek follows the same periodization of the textual data, i.e., period I: $1200-135^{\circ}$, period II: $135^{\circ}-145^{\circ}$ and period III:1450-1550. She finds that in period I the NPs containing en 'one' are (if $e n$ is not to be understood as a cardinal) overwhelmingly initially placed subjects, introducing new and persistent discourse referents (Heim 1988), with a number of subsequent mentions (Skrzypek 2012:161170). She also finds such use to be cataphoric and parallel to the origins of the definite article (in terms of the marking of salient discourse referents first).

(117) En velburin ungar suen forlet verud-ena ok folgpe EN well.born young boy left world-DEF and followed andream: hans frcendar vildo pøm bapa inne brcenna ok Andreas his relatives wanted them both in burn and tcendo brand iui pera herbcerghe Smasuenn-en slakte balet lit fire over their shelter small.boy-DeF quenched fire $m z$ litlo vatne $p a$ vildo pe kliva $i$ hus-et ok with some water then wanted they step in house-DEF and wrpo alle iœmskyt blinde: pa opte en at allom: vape became all suddenly blind then called one to all danger cer striba vip gup som siceluan haldar $\mathrm{mz}$ andrea. ok is fight with God which self holds with Andreas and pøm hanom folgher her af worpo mange cristne. ok them him follow this of became many Christian and tropo py andreas prcedicape

believed this Andreas preached 'A well-born young man left the world and followed Andreas. His relatives wanted to burn them (alive) and started a fire over their shelter. The young man put out the fire with some water. Then they wanted to enter the house and became all suddenly blind. Then one called to all: it is dangerous to fight against God himself who protects Andreas and all who follow him. Because of this many became Christian and believed what Andreas preached.' (Bur 133; Skrzypek 2012:164)

Stendahl (2013) is a monographic study of the grammaticalization of the indefinite article in Swedish which spans the same time as the two previous studies, but subdivides it into four periods, allowing an even more fine-grained picture. His choice of texts includes genres of high narrativity, and excludes legal prose, as the author treats lack of articles as a particular property of legal material (Stendahl 2013:9o). He does not follow Heine's model, but groups the uses of 
en into categories, or strategies (for instance, to mark non-referential nouns as well). His interpretation of the results places the formation of the indefinite article in Swedish quite early, at the beginning of the 14th century; he also finds that any discrepant uses of en, or rather its absence, are due to stylistic factors rather than being a diagnostic of incomplete grammaticalization (Stendahl 2013:161). Even though the indefinite article in Swedish seems to be very well studied diachronically, there remain differences between authors as to the time at which its grammaticalization took place.

\subsection{Summary}

In this chapter, we have discussed functions of the definite and indefinite article cross-linguistically, as well as the models of their grammaticalization proposed in literature and earlier research into the rise of articles in North Germanic languages.

Definite articles regularly develop out of deictic elements and their origins can be traced in the earlier stages of grammaticalization, which involve the direct anaphoric reference, i.e., reference to a previously mentioned entity. It seems that rather than being confined to an immediate situation, the use of the original deictic element is extended to encompass textual deixis, direct anaphora. The grammaticalization then proceeds via indirect anaphoric use, in which the incipient definite article is used with new referents, which are grounded in earlier discourse, to the unique reference, in which the definite article is used as a marker of the uniqueness of the referent. The uniqueness corresponds to Hawkins' larger situation use, in which a referent can be identified as being the only one satisfying the description within a given situation. Such situations can be of varying size, from local, e.g., a room, to global, e.g., the entire universe. Existing models of definite article grammaticalization propose that in the course of the process these functions are gradually encompassed by the incipient definite article in this order, however, the bridging contexts from one definite article function to the next remain unclear.

Indefinite articles seem to universally stem from the numeral 'one'. As with the definite article, also the indefinite article appears in a multitude of functions, which do not arise simultaneously. The proposed grammaticalization models, which have been successfully tested on data from a number of languages, single out the presentative use as the onset of the development. The incipient indefinite article is used to present new and salient discourse referents. The consecutive stages involve the introduction of specific discourse referents, new, but not necessarily salient, and finally the non-specific use of the 
erstwhile numeral. The final stage of both grammaticalizations is the generic use of the articles, in which the known: new distinction, so pervasive in earlier stages of the process, becomes obliterated.

Dryer (1989) demonstrates that articles are present in only one-third of the world's languages. The definite article is more wide-spread than the indefinite, meaning that if a language has an indefinite article it is very likely to have the definite also (see also Moravcsik 1969, Heine 1997, Dryer 2013a, 2013b), although some exceptions have been found. Diachronically, it is easily observable that the definite article predates the indefinite, at least to some extent, i.e., the grammaticalization of the indefinite begins only when the grammaticalization of the definite is already well underway. In this sense, the discrepancy between the frequencies of the two articles in the world's languages can be understood as a result of complete grammaticalization of the definite article without the grammaticalization of the indefinite. In other words, the fact that the grammaticalization of the indefinite follows the grammaticalization of the definite does not imply that it must occur. A language may only develop one article and make use of zero determination to express the indefinite meanings. This is the case with Icelandic, one of the languages in our sample, although we will modify the claim of its not having developed the indefinite article somewhat in Chapter 5 . Even when a language has grammaticalized both the definite and the indefinite article, it may still retain a residual domain of zero determination, which in turn may also undergo a grammaticalization process of its own.

The first stages of the grammaticalization of both definite and indefinite articles as identified in grammaticalization chains above are textual. The anaphoric use of the original demonstrative helps select a discourse referent known from previous discourse, especially one that has not been in focus for some time (De Mulder and Carlier 2011:527). The presentative use of the original numeral 'one' helps prepare the hearer for a new, salient discourse referent. We discern a certain symmetry in the earliest stages of both grammaticalization processes: discourse referents are presented by means of incipient articles for a stronger pragmatic impact. We may further say that while the original use of the definite article is anaphoric, the original use of the indefinite is cataphoric. At the same time, as the data from many languages indicate, it is not in any way necessary for a language to develop this symmetry. The incipient definite article may go on to grammaticalize successive functions without having any indefinite opposite number other than a bare noun.

In Chapters 4 and 5 we test the proposed models of article grammaticalization against data from a North Germanic corpus. Two approaches are combined: quantitative (Chapter 4 ) and qualitative (Chapter 5 ). Our aim is to verify 
the chronology of definite and indefinite article use in contexts identified as consecutive stages of grammaticalization, as well as to provide examples of contexts that may have been critical for the development. 